\title{
A CESSÃO TEMPORÁRIA DE ÚTERO: UMA ANÁLISE SOBRE A (IM)POSSIBILIDADE CONTRATUAL À LUZ DO DIREITO CIVIL CONSTITUCIONALIZADO*
}

\author{
Priscila Maria da Silva Pereira*** \\ Ana Lucia Brunetta Cardoso****
}

\section{RESUMO}

A reprodução humana assistida é uma realidade trazida pelo progresso da biotecnologia, servindo de mecanismo para aqueles impossibilitados de gerar o próprio filho. Entre os métodos trazidos pela ciência está a cessão temporária de útero para gestação. A participação de um terceiro alheio ao projeto parental faz ruir todo o sistema tradicional de presunções de filiação. Diante da inexistência de legislação sobre o tema, é fundamental o aprofundamento do seu estudo. Por tratar da vida humana, o texto aborda a cessão temporária de útero para a gestação analisando a existência ou não de violação dos direitos fundamentais presentes no ordenamento brasileiro, passando pela verificação da possibilidade de estabelecer um contrato, gratuito ou oneroso, à luz do Direito Civil constitucionalizado e encerrando com a análise sobre a filiação a ser atribuída nesses casos. A pesquisa serve de fomento às discussões jurídicas, bem como a outros estudos referentes à necessidade de implementação de uma legislação especial concernente ao assunto.

Palavras-chave: Gestação substitutiva. Cessão temporária de útero. Direitos fundamentais. Contrato. Filiação.

* Artigo apresentado ao Curso de Bacharelado em Direito do Centro Universitário Metodista - IPA, como requisito parcial para obtenção do Grau de Bacharel em Direito.

** Graduando do Curso de Bacharelado em Direito do Centro Universitário Metodista - IPA.

*** Orientadora do artigo, Mestre em Direito Ambiental e Biodireito pela Universidade de Caxias do Sul e professora do Curso de Bacharelado em Direito do Centro Universitário Metodista - IPA. 


\title{
SURROGATE BIRTH: AN ANALYSIS OF THE CONTRACTUAL (IM)POSSIBILITY IN LIGHT OF THE CONSTITUTIONALIZED CIVIL LAW
}

\begin{abstract}
Assisted human reproduction is a reality brought about by the progress of biotechnology, serving as a mechanism for those prevented from producing their own child. Among the methods introduced by science is surrogacy. The participation of a third person unrelated to the parental project makes the whole traditional system of presumptions of parentage collapse. In the face of an absence of legislation about the subject, further development of its study is essential. As a result of addressing human life, the text reviews surrogacy analyzing the existence or inexistence of a violation of the fundamental rights present in the Brazilian legal framework, undergoing the verification of the possibility of framing a gratuitous or onerous contract in light of the constitutionalized Civil Law and concludes with an analysis of the filiation to be attributed in such cases. This research serves as encouragement to legal debate, as well as to other studies concerning the need to implement special legislation pertaining to the subject.
\end{abstract}

Key words: Substitutive gestation. Surrogacy. Fundamental rights. Contract. Filiation.

\section{INTRODUÇÃO}

0 presente artigo apresenta como tema a cessão temporária de útero para a gestação, analisando a possibilidade de celebração de um contrato no Direito Civil constitucionalizado.

No Brasil, os casos de infertilidade de casais apresentam taxas elevadas e a cessão temporária de útero surge como uma alternativa para solução dessa grave questão que assola os indivíduos, à medida que se apresenta como um meio para a tão sonhada formação familiar. Ocorre que o tema não possui uma normativa jurídica estabelecida pelo Poder Legislativo, com alguns projetos de lei criados, mas que não chegaram à concretização em lei.

Apesar de a ciência ter avançado nas técnicas de reprodução humana, percebe-se que a regulamentação jurídica da utilização desses métodos tem se dado a passos lentos, fazendo com que 
muitos interessados desistam do procedimento no país por receio quanto às repercussões jurídicas ou, até mesmo, realizem o procedimento em outros países que legalmente permitem a utilização e estabelecem o seu regramento.

Nesse sentido o trabalho traz como problema de pesquisa norteador: na cessão temporária de útero há possibilidade de celebração de um contrato segundo as normas do Direito Civil constitucionalizado?

Cabe ressaltar que, diante da ausência de legislação brasileira específica que regulamente a cessão temporária de útero, o Conselho Federal de Medicina editou resoluções que orientam os médicos na realização dos procedimentos de reprodução humana assistida e estabelece os requisitos necessários àqueles que desejam fazer uso de tais técnicas.

Sob esse enfoque, o trabalho discorre sobre a cessão temporária de útero no Brasil e os casos em que o procedimento é permitido no país. Aborda a forma como os procedimentos estão sendo autorizados e os instrumentos jurídicos utilizados para a celebração do acordo entre as partes.

A hipótese levantada através do estudo é a de que o estabelecimento de um contrato de cessão temporária de útero supre a ausência legislativa sobre o tema, ao conferir aos pactuantes a segurança jurídica atinente aos contratos.

0 objetivo geral do trabalho é investigar a atual realidade brasileira das famílias que desejam utilizar a cessão temporária de útero, os requisitos necessários e o instrumento a ser utilizado para a perfectibilização do ato no mundo jurídico. Como objetivos específicos a pesquisa pretende: verificar os direitos constitucionais atinentes à cessão temporária de útero, identificar os limites de disposição do corpo frente ao direito ao planejamento familiar no contexto da cessão temporária de útero, bem como verificar as consequências da filiação nesse tipo de gestação. 
Foi utilizado o método dedutivo para a prática da investigação, pois, com base em premissas se pretendeu atingir uma conclusão necessária.

O tipo de pesquisa usado foi o bibliográfico, utilizando-se de livros, artigos, teses doutrinárias, bem como dos dados trabalhados por outros, além do documental, de maneira complementar.

Diante da inércia do Poder Legislativo, tratar da possibilidade de existência de um contrato que pactue a cessão temporária de útero entre as partes é um primeiro passo para solucionar o problema de ausência de regramento legal sobre o assunto, à medida que seriam aplicáveis as garantias conferidas aos contratos no Direito Civil constitucionalizado.

Com as informações e análises abordadas no trabalho em questão, o mesmo cumpre com a sua função de relevância social. Serve de fomento às discussões jurídicas sobre o assunto, bem como a outros estudos referentes à necessidade de implementação de um regramento jurídico, de maneira a proporcionar a concretude do direito ao planejamento e formação familiar.

\section{A REPRODUÇÃO HUMANA ASSISTIDA}

0 desejo de formar uma família muitas vezes esbarra em limitações impostas pela natureza. Com a capacidade de gerar comprometida, muitos casais necessitam de auxílio da ciência e tecnologia para concretizar a expansão do núcleo familiar.

Segundo a Organização Mundial de Saúde - OMS, a infertilidade caracteriza-se quando após um ano de vida sexual ativa, sem o uso de métodos contraceptivos, não há gestação. ${ }^{1}$ As técnicas

\footnotetext{
ZEGERS-HOCHSCHILD, F.; ADAMSON, G.D.; MOUZON, J.; ISHIHARA, O.; MANSOUR, R.; NYGREN, K.; SULLIVAN, E.; VANDERPOEL S. Glossário revisado da Terminologia das Técnicas de Reprodução Assistida (TRA), 2009, Comitê Internacional para Monitorização da Tecnologia Reprodutiva Assistida (ICMART) e Organização Mundial da Saúde (OMS). 2010. Disponível em: <http://www.who.int/reproductivehealth/publications/ infertility/art_terminology_por.pdf >. Acesso em: 05 jun. 2018.
} 
de reprodução humana assistida surgem como uma solução para os casos de infertilidade, muitas vezes utilizadas após a tentativa frustrada de casais inférteis a outros métodos.

Segundo Maria Helena Diniz, a reprodução humana assistida consiste em "um conjunto de operações para unir, artificialmente, os gametas feminino e masculino, dando origem a um ser humano".

\subsection{BREVE HISTÓRICO DA REPRODUÇÃO}

Historicamente, o assunto sempre foi um tema delicado, sendo possível encontrarmos registros sobre o desejo dos indivíduos em procriarem ainda na Antiguidade.

O Código de Hammurabi permitia que a esposa oferecesse uma criada ao marido para a procriação, conforme tradução de Bouzon:

$\S 144$ - Se um awilum tomou uma naditum por esposa e essa naditum deu a seu esposo uma escrava e esta lhe gerou filhos; (se) esse awilum decidiu tomar por esposa uma sugitum, eles não permitirão (isso) a esse awilum, ele não poderá tomar por esposa a sugitum.

$\S 145$ - Se um awilum tomou por esposa uma naditum e ela não lhe obteve filhos; (se) esse awilum decidiu tomar por esposa uma sugitum, esse awilum poderá tomar a sugitum como esposa e introduzi-la em sua casa. Essa sugitum não será, (contudo), igualada à naditum. ${ }^{3}$

Eduardo de Oliveira Leite lembra da referência já trazida pela Bíblia $^{4}$ a qual menciona em Gênesis, capítulo XVI, versículos 1 a 4,

2 DINIZ, Maria Helena. 0 estado atual do biodireito. 2. ed. São Paulo: Saraiva, 2002. p. 475.

3 BOUZON, Emanuel (Org). 0 código de Hammurabi. 10. ed. Petrópolis: Vozes, 2003. p. 149.

4 Compilado de textos escritos ao longo de mais de 1.500 anos, considerado sagrado pelos cristãos. Aqui utilizada como elemento de contextualização do período histórico compreendido entre 1500 a.C. e 450 a.C. 
o caso de Sara e Abraão, no momento em que Sara, infértil, pede que o esposo engravide uma escrava e, assim, conceba um filho ${ }^{5}$ :

1.Ora Sarai, mulher de Abrão, não lhe dava filhos, e ele tinha uma serva egípcia, cujo nome era Agar. 2. E disse Sarai a Abrão: Eis que o Senhor me tem impedido de dar à luz; toma, pois, a minha serva; porventura terei filhos dela. E ouviu Abrão a voz de Sarai.

3. Assim tomou Sarai, mulher de Abrão, a Agar egípcia, sua serva, e deu-a por mulher a Abrão seu marido, ao fim de dez anos que Abrão habitara na terra de Canaã.

4. E ele possuiu a Agar, e ela concebeu; e vendo ela que concebera, foi sua senhora desprezada aos seus olhos. ${ }^{6}$

Em outra passagem, capítulo XXX, versículos 1 a 6, também em Gênesis, Raquel também solicita a Jacob, seu esposo, que gere um filho com a escrava:

1.Vendo Raquel que não dava filhos a Jacó, teve inveja de sua irmã, e disse a Jacó: Dá-me filhos, se não morro.

2.Então se acendeu a ira de Jacó contra Raquel, e disse: Estou eu no lugar de Deus, que te impediu o fruto de teu ventre?

3.E ela disse: Eis aqui minha serva Bila; coabita com ela, para que dê à luz sobre meus joelhos, e eu assim receba filhos por ela.

4.Assim lhe deu a Bila, sua serva, por mulher; e Jacó a possuiu.

5 LEITE, Eduardo de Oliveira (Coord). Grandes temas da atualidade: bioética e biodireito. Rio de Janeiro: Forense, 2004. p. 6.

6 BÍBLIA. A. T. Gênesis. In: BÍBLIA. Português. Bíblia sagrada. Tradução de João Ferreira de Almeida. Sociedade Bíblica do Brasil, 1993. Disponível em: < http://biblia.com.br/joao-ferreira-almeida-corrigida-revisada-fiel/>. Acesso em: 04 out. 2018. 
5.E concebeu Bila, e deu a Jacó um filho.

6.Então disse Raquel: Julgou-me Deus, e também ouviu a minha voz, e me deu um filho; por isso chamou-lhe Dã. ${ }^{7}$

A mulher estéril era tida como uma pessoa sem sorte e até mesmo amaldiçoada. Os judeus acreditavam que a esterilidade ocorria como um castigo de Deus, quanto que a fertilidade estava atrelada à fartura, riqueza, benevolência e dádiva divina. Apenas no século XVII foi admitida que a esterilidade não fosse apenas feminina, como também masculina. ${ }^{8}$

A esterilidade passa a atingir o indivíduo na sua própria identidade ao desencadear reações negativas como angústia, depressão e raiva, que afetam o casal quando frustrado o projeto parental e que se refletem no ambiente familiar com uma projeção mais larga. ${ }^{9}$ Leite aponta que inúmeras são as motivações, íntimas e sociais, para ter um filho: reproduzir na linhagem ancestral, estabelecer uma relação ideal entre pais e filhos, recriar sua própria infância, presentear o companheiro (a), evitar a solidão em anos futuros, entre outros. ${ }^{10}$

A procriação artificial surgiu então como um meio dado pela ciência para contornar a infertilidade. Há registros que a fecundação por inseminação assistida em seres humanos teve

7 BÍBLIA. A. T. Gênesis. In: BÍBLIA. Português. Bíblia sagrada. Tradução de João Ferreira de Almeida. Sociedade Bíblica do Brasil, 1993. Disponível em: < http://biblia.com.br/joao-ferreira-almeida-corrigida-revisada-fiel/>. Acesso em: 04 out. 2018.

8 LEITE, Eduardo de Oliveira. Procriações artificiais e o direito: aspectos médicos, religiosos, psicológicos, éticos e jurídicos. São Paulo: Revista dos Tribunais, 1995. p. 17-18.

9 LEITE, Eduardo de Oliveira. Procriações artificiais e o direito: aspectos médicos, religiosos, psicológicos, éticos e jurídicos. São Paulo: Revista dos Tribunais, 1995. p. 22.

10 LEITE, Eduardo de Oliveira. Procriações artificiais e o direito: aspectos médicos, religiosos, psicológicos, éticos e jurídicos. São Paulo: Revista dos Tribunais, 1995. p. 69. 
sua primeira experiência exitosa no ano de 1799, com o médico inglês John Hunter. ${ }^{11}$

A reprodução assistida teve como marco histórico o nascimento do primeiro bebê de proveta do mundo, Louise Brown, em 1978. A mãe, Lesley Brown, era estéril em razão de uma obstrução nas trompas de falópio, sendo-lhe retirado o óvulo, fecundado em tubo de ensaio com o sêmen de seu marido, John Brown, e implantado o embrião em seu útero. 0 embrião teve um desenvolvimento normal, nascendo Louise. ${ }^{12}$

Segundo Heloisa Helena Barboza, a partir desse momento, as discussões sobre o emprego das técnicas de reprodução assistida se ampliaram no mundo. ${ }^{13}$

No Brasil, Anna Paula Caldera, foi o primeiro bebê de proveta, nasceu em outubro de 1984 e até hoje é considerada um símbolo para aqueles que desejam se valer da reprodução assistida. ${ }^{14}$

É verdade que na pós-modernidade surgiram novos arranjos familiares, que deram destaque para o vínculo de afeto, superando o biológico e genético, valorizando o caráter socioafetivo das relações familiares nos diversos modelos de famílias homossexuais, monoparentais, informais, anaparentais e eudemonistas, conforme descreve Maria Berenice Dias. ${ }^{15}$

Contudo, é preciso assegurar o direito daqueles que desejam a procriação para a constituição familiar, através do uso das

11 SAUWEN, Regina Fiuza; HRYNIEWICZ, Severo. O Direito “in vitro" da bioética ao biodireito. 3. ed. Rio de Janeiro: Lumen Juris, 2008. p. 86.

12 DINIZ, Maria Helena. 0 estado atual do biodireito. 2. ed. São Paulo: Saraiva, 2002. p. 489.

13 BARBOZA, Heloisa Helena. Reprodução assistida e o novo Código Civil. In: SÁ, Maria de Fátima Freire de; NAVES, Bruno Torquato de Oliveira (Org). Bioética, biodireito e o novo Código Civil de 2002. Belo Horizonte: Del Rey, 2004. p. 225.

14 DINIZ, Maria Helena. 0 estado atual do biodireito. 2. ed. São Paulo: Saraiva, 2002. p. 489.

15 DIAS, Maria Berenice. Manual de Direito das famílias. Porto Alegre: Livraria do Advogado, 2005. p. 38-48. 
técnicas de reprodução assistida, independente do "modelo" de família em que estejam inseridos.

\subsection{DAS PRESUNÇÕES DE FILIAÇÃO}

Cabível referir, ainda que resumidamente, as maneiras utilizadas pelo direito para estabelecimento da filiação, permitindo assim uma melhor análise diante dos avanços da ciência.

0 Direito Romano inicialmente adotou como critério de parentesco do mesmo núcleo familiar o integrante que professasse o mesmo culto do pater familias. Aquele filho que renunciasse ao culto era considerado estranho à família e o adotado que a seguisse era considerado membro da família, pois o chefe patriarcal era autoridade religiosa, econômica e jurídica de todos os membros do clã. ${ }^{16}$

Com o fortalecimento do Estado Romano e o avanço do Cristianismo, o Estado expande o seu território garantindo sua supremacia econômica e o monopólio da Justiça. 0 Estado, a partir do Imperador Constantino, passa a enfraquecer a potestade, considerando mais valioso o vínculo sanguíneo, em detrimento da vontade do patriarca em abrigar pessoa que dele não era descendente direto. ${ }^{17}$

No Brasil, a consanguinidade e a legitimidade em decorrência do matrimônio foram importantes desde as Ordenações Filipinas. A Igreja Católica passou a distinguir a filiação legítima, concebida dentro do casamento, e a ilegítima, conferindo mais direitos aos filhos legítimos. ${ }^{18}$

O Código Civil de 1916 impedia o reconhecimento de paternidade dos filhos adulterinos e incestuosos. As presunções de

16 AGUIAR, Mônica. Direito à filiação e bioética. Rio de Janeiro: Forense, 2005. p. 2.

17 AGUIAR, Mônica. Direito à filiação e bioética. Rio de Janeiro: Forense, 2005. p. 4.

18 AGUIAR, Mônica. Direito à filiação e bioética. Rio de Janeiro: Forense, 2005. p. 5. 
filiação foram aceitas por muito tempo, e adotadas pelo legislador de 1916. Paulo Lôbo elencou as principais presunções do Código Civil de $1916^{19}$, utilizadas para conferir paternidade ou maternidade a alguém:

a) a presunção pater is est quem nuptia demonstrant, impedindo que se discuta a origem da filiação se o marido da mãe não a negar em curto prazo preclusivo;

b) a presunção mater semper certa est, impedindo a investigação de maternidade contra mulher casada;

c) a presunção de paternidade atribuída ao que teve relações sexuais com a mãe, no período da concepção;

d) a presunção de exceptio plurium concumbentium que se opõe à presunção anterior;

e) a presunção de paternidade, para os filhos concebidos 180 dias antes do casamento e 300 dias após a dissolução da sociedade conjugal, entre outros. ${ }^{20}$

A filiação materna sempre foi estabelecida de maneira mais cômoda, completa e definitiva, através da prova que uma mulher teve um parto e da identidade entre o parto e a criança oriunda do mesmo. A própria palavra parentesco, derivada do latim pário-ére, significa parir, gerar. Daí surgiu a expressão mater semper certa est, pois, em princípio, não há dúvida sobre a filiação materna. ${ }^{21}$

19 BRASIL. Lei no $\mathbf{3 . 0 7 1}$ de 1o de janeiro de 1916 [Código Civil dos Estados Unidos do Brasil]. Disponível em: < http://www.planalto.gov.br/ccivil_03/ Leis/L3071.htm>. Acesso em: 13 mai. 2018.

20 LÔBO, Paulo. Princípio jurídico da afetividade na filiação. Revista Jus Navigandi, ISSN 1518-4862, Teresina, ano 5, n. 41, 1 maio 2000. Disponível em: <https://jus.com.br/artigos/527/>. Acesso em: 2 out. 2018.

21 LEITE, Eduardo de Oliveira. Procriações artificiais e o direito: aspectos médicos, religiosos, psicológicos, éticos e jurídicos. São Paulo: Revista dos Tribunais, 1995. p. 359. 
Já para a paternidade foram estabelecidas presunções e probabilidades com origem no ato sexual, seguido de concepção e nascimento da criança que vigoraram até o século passado. ${ }^{22}$ A presunção pater is est quem justae nuptia demonstrat é originária da presunção de coabitação e fidelidade da mulher, a qual estabelece a paternidade do filho, havido dentro do casamento, pelo marido da mulher casada. ${ }^{23} \mathrm{~A}$ presunção funcionava como uma forma de assegurar a solidez da família. ${ }^{24}$

A Constituição Federal de 1988 (CF) conferiu a igualdade de direitos e qualificações aos filhos concebidos ou não no casamento (art. 227, § 6으, CF), refletindo o estado fático, reconhecendo que a família pode ou não decorrer do casamento. 0 Código Civil de 2002 (CC) repetiu, no artigo 1.596, o disposto na Constituição.

As reformas que ocorreram no direito de filiação foram levadas pelo avanço da engenharia genética, principalmente o exame de $\mathrm{DNA}^{25}$, que conferiu abertura à verdade biológica. A ficção jurídica de presunções dá espaço a quase certeza sobre a paternidade. ${ }^{26}$

22 DIAS, Maria Berenice. Manual de Direito das famílias. 4.ed. São Paulo: Revista dos tribunais, 2016. p. 669.

23 LEITE, Eduardo de Oliveira. Procriações artificiais e o direito: aspectos médicos, religiosos, psicológicos, éticos e jurídicos. São Paulo: Revista dos Tribunais, 1995. p. 359.

24 SAUWEN, Regina Fiuza; HRYNIEWICZ, Severo. 0 Direito "in vitro" da bioética ao biodireito. 3. ed. Rio de Janeiro: Lumen Juris, 2008. p. 100.

25 LOPES, Érica Camelo Viana; COSTA, Vanessa Duarte; BARCELOS, Rejane da Silva Sena. Banco de Dados de DNA na Área Forense: uma Realidade Brasileira. Brazilian Journal of Forensic Sciences, Goiás, v. 2, n. 4, 30 setembro 2013. Disponível em: < http://www.ipebj.com.br/forensicjournal/download. php?arquivo $=100>$. Acesso em: 12 nov. 2018.

Técnica de identificação fundamentada na análise direta da molécula do ácido desoxirribonucléico (significado da sigla DNA: Deoxyribonucleic Acid).

26 SAUWEN, Regina Fiuza; HRYNIEWICZ, Severo. O Direito “in vitro” da bioética ao biodireito. 3. ed. Rio de Janeiro: Lumen Juris, 2008. p. 101. O autor menciona o grau de acerto do exame de DNA de 99,999999\%, e possibilidade de erro de 1/100 milhões. Somadas as provas testemunhais e circunstanciais, a margem de erro torna-se irrelevante. 
A evolução da biotecnologia e da diversidade de técnicas de reprodução humana assistida refletiu na estrutura da família, fazendo ruir toda sistemática de presunção de paternidade, maternidade e filiação. ${ }^{27}$ Gomes faz uma pertinente reflexão sobre a complexidade jurídica da filiação diante da bioética:

Propõe-se o estudo de um dos temas mais áridos
do direito de família, qual seja, a questão da filia-
ção, sob o enfoque do entrelaçamento do direito
com a bioética. Justifica-se a escolha a partir do
momento em que se analisam os dois maiores
avanços científicos que acabaram por antecipar
amplas revoluções em sede familiar, bastando
para tanto o desmembramento das idéias - antes
indissociáveis - de relação sexual e concepção. Em
um primeiro momento, com a descoberta da pílula
contraceptiva, torna-se possível sexo sem procria-
ção. Em um segundo estágio, a ciência permite a
procriação sem sexo.

Sauwen leciona que, em observância a história das culturas, a impossibilidade de gerar filhos costuma seguir três constantes:

1. cada sociedade desenvolve um meio de driblar a infertilidade;

2. a solução encontrada, em geral, leva um certo tempo até ser incorporada aos costumes do grupo;

3. quando determinada sociedade inscreve em seu código de conduta um tipo de filiação, este costuma de fato funcionar. ${ }^{29}$

27 DIAS, Maria Berenice. Manual de Direito das famílias. 4.ed. São Paulo: Revista dos tribunais, 2016. p. 669.

28 GOMES, Renata Raupp. A relevância da bioética na construção do novo paradigma da filiação na ordem jurídica nacional. In: LEITE, Eduardo de Oliveira (Coord). Grandes temas da atualidade: bioética e biodireito. Rio de Janeiro: Forense, 2004. p. 339.

29 SAUWEN, Regina Fiuza; HRYNIEWICZ, Severo. O Direito “in vitro” da bioética ao biodireito. 3. ed. Rio de Janeiro: Lumen Juris, 2008. p. 98. 


\subsubsection{A filiação na procriação assistida}

A dissociação da sexualidade e reprodução modifica as estruturas habituais e empresta significado à vontade, pois a filiação deixa de ser exclusivamente biológica, mas também a ser desejada, numa paternidade de intenção. ${ }^{30}$

0 Código Civil de 2002 acrescentou, no artigo 1.597, mais três hipóteses de presunção de paternidade, relativas ao direito de filiação na procriação assistida:

Art. 1.597. Presumem-se concebidos na constância do casamento os filhos:

(...)

III - havidos por fecundação artificial homóloga, mesmo que falecido o marido;

IV - havidos, a qualquer tempo, quando se tratar de embriões excedentários, decorrentes de concepção artificial homóloga;

V - havidos por inseminação artificial heteróloga, desde que tenha prévia autorização do marido.

A inclusão dessas presunções foi considerada tímida pelos doutrinadores, que acreditam que a justificativa se deve à imaturidade do tema com teor altamente técnico. ${ }^{31} \mathrm{Em} 2003$ foi emitido enunciado em Jornada de Direito Civil, no 126 , promovido pelo Centro de Estudos Judiciários do Conselho da Justiça Federal, que propôs alteração das expressões usadas pelo legislador ("fecundação artificial", "concepção artificial" e "inseminação artificial heteróloga") para "técnicas de reprodução assistida", dada a impropriedade do termo "artificial' uma vez que a fecundação ainda que conte com auxílio técnico é sempre natural, e do termo "inseminação artificial heteróloga", pois esse é apenas um dos métodos de reprodução in vitro. ${ }^{32}$

30 LEITE, Eduardo de Oliveira. Procriações artificiais e o direito: aspectos médicos, religiosos, psicológicos, éticos e jurídicos. São Paulo: Revista dos Tribunais, 1995. p. 361.

31 DIAS, Maria Berenice. Manual de Direito das famílias. 4.ed. São Paulo: Revista dos tribunais, 2016. p. 670.

32 AGUIAR, Mônica. Direito à filiação e bioética. Rio de Janeiro: Forense, 2005. p. 15. 
Tratando-se de fecundação artificial homóloga (aquela em que o material genético utilizado é do próprio casal), inexiste necessidade de autorização do marido/companheiro, pois o vínculo de paternidade foi estabelecido geneticamente. ${ }^{33}$

Na fecundação artificial heteróloga é necessária a prévia manifestação expressa de concordância do marido/companheiro para que sua esposa/companheira utilize o sêmen de terceira pessoa. Segundo Maria Berenice Dias a manifestação é correspondente a uma adoção antenatal que revela o desejo de ser pai. Essa manifestação inadmite retratação e gera presunção juris et de jure, não podendo ser impugnada, tratando-se de presunção absoluta de paternidade socioafetiva, em observância ao princípio de paternidade responsável. ${ }^{34}$

A partir da participação temporária de uma pessoa alheia aos autores do projeto parental, tem-se como reflexo jurídico direto da gestação de substituição a questão da filiação, maternidade e paternidade, da criança gerada.

A presunção mater semper cesta est deve ser relativizada, sendo mantida somente em relação ao parto decorrente de atividade sexual dos parceiros, pois a mãe geradora pode não ser a mãe genética. ${ }^{35}$ Assim, o desejo a maternidade e a gravidez dissociam-se, dada a impossibilidade de gestar. ${ }^{36}$

Nos casos em que houve apenas a utilização do útero alheio, a maternidade deve ser atribuída à mulher que quis o filho e assentiu na inseminação. A complexidade se dá nos casos de ga-

33 DIAS, Maria Berenice. Manual de Direito das famílias. 4.ed. São Paulo: Revista dos tribunais, 2016. p. 671.

34 DIAS, Maria Berenice. Manual de Direito das famílias. 4.ed. São Paulo: Revista dos tribunais, 2016. p. 674.

35 AGUIAR, Mônica. Direito à filiação e bioética. Rio de Janeiro: Forense, 2005. p. 114.

36 GAMA, Guilherme Calmon Nogueira da. A nova filiação: o biodireito e as relações parentais: o estabelecimento da parentalidade-filiação e os efeitos jurídicos da reprodução assistida heteróloga. Rio de Janeiro: Renovar, 2003. p. 745. 
meta proveniente de doação e implantação em útero cedido para a fertilização in vitro, pois supostamente teríamos três maternidades se analisássemos individualmente: a genética (doadora do material genético), a portadora (em razão do parto) e a afetiva (da qual a vontade de procriar ensejou a utilização da técnica). ${ }^{37}$ No entanto, a fixação da maternidade deve ser dada àquela que desejou procriar. Segundo Gama, a vontade, inserida no projeto parental, aliada à contribuição de outras pessoas, deverá servir de pressuposto que substitui a relação sexual. ${ }^{38}$

\section{CESSÃO TEMPORÁRIA DE ÚTERO}

\subsection{DA ORIGEM E CONCEITO}

Os primeiros casos registrados de empréstimo de útero teriam ocorrido em 1963, no Japão, e 1975, nos Estados Unidos. 0 procedimento é indicado para a infertilidade vinculada a uma ausência, congênita ou adquirida, do útero, patologia uterina ou contraindicação médica à gravidez, que leve a uma absoluta impossibilidade de gestar. $^{39}$

A cessão temporária de útero também é conhecida por outros termos como maternidade substitutiva, gestação de substituição ou substitutiva, barriga de aluguel, maternidade sub-rogada, útero de empréstimo, entre outros.

De acordo com Francisco Vieira Lima Neto a cessão temporária de útero consiste num procedimento de reprodução humana assistida que realiza a transferência de embriões ao útero

37 AGUIAR, Mônica. Direito à filiação e bioética. Rio de Janeiro: Forense, 2005. p. 114.

38 GAMA, Guilherme Calmon Nogueira da. A nova filiação: o biodireito e as relações parentais: o estabelecimento da parentalidade-filiação e os efeitos jurídicos da reprodução assistida heteróloga. Rio de Janeiro: Renovar, 2003. p. 747.

39 LEITE, Eduardo de Oliveira. Procriações artificiais e o direito: aspectos médicos, religiosos, psicológicos, éticos e jurídicos. São Paulo: Revista dos Tribunais, 1995. p. 66. 
de uma mulher que o "empresta" a um casal impossibilitado de gestar. ${ }^{40}$ Portanto, fazem parte da relação: um casal ${ }^{41}$ que deseja uma criança (e é impossibilitado de gestar) e uma mulher que cedeu seu útero temporariamente (chamada de portadora ou nidadora) para o desenvolvimento da criança até o nascimento e que a entregará ao casal (autor do projeto parental) após o parto.

Eduardo de Oliveira Leite entende por maternidade substitutiva, do ponto de vista médico, que:

(...) a maternidade substitutiva pode ocorrer com a transferência de embriões ao útero de uma mulher que o alugue ou empreste, ou através de uma inseminação artificial ou FIV em que a mulher ponha o seu óvulo, além do útero. ${ }^{42}$

Há duas técnicas para a realização dos procedimentos de inseminação artificial: a homóloga e a heteróloga. Na primeira, o casal possui aptidão biológica para a procriação, porém devido a uma anomalia física a fertilização natural é impossível. Vejamos a lição de Silvio Venosa no que concerne a este primeiro ponto:

A inseminação homóloga pressupõe que a mulher seja casada ou mantenha união estável e que o sêmen provenha do marido ou companheiro. É utilizada em situações nas quais, apesar de ambos os cônjuges serem férteis, a fecundação não é possível

40 LIMA NETO, Francisco Vieira. A maternidade de substituição e o contrato de gestação por outrem. In: SANTOS, Maria Celeste Cordeiro Leite (Org). Biodireito: ciência da vida, os novos desafios. São Paulo: Revista dos Tribunais, 2001. p. 126.

41 CONSELHO FEDERAL DE MEDICINA (CFM). Resolução CFM no 2.168/2017. Disponível em <https://sistemas.cfm.org.br/normas/visualizar/resolucoes/ BR/2017/2168>. Acesso em: 26 set. 2018.

A Resolução do CFM no 2.168/2017 prevê a possibilidade de utilização também em união homoafetiva e pessoa solteira.

42 LEITE, Eduardo de Oliveira (Coord). Grandes temas da atualidade: bioética e biodireito. Rio de Janeiro: Forense, 2004. p. 7. 
por meio do ato sexual por várias etiologias (problemas endócrinos, impotência, vaginismo, etc.). ${ }^{43}$

Já na segunda técnica, o material genético utilizado é alheio ao casal, sendo proveniente de outra pessoa não haverá vínculo biológico com a criança. Continua o autor explanando:

A inseminação heteróloga é aquela cujo sêmen é de um doador que não o marido. Aplica-se principalmente nos casos de esterilidade do marido, incompatibilidade do fator $\mathrm{Rh}$, moléstias graves transmissíveis pelo marido etc. Com freqüência, recorre-se aos chamados bancos de esperma, nos quais, em tese, os doadores não são e não devem ser conhecidos. ${ }^{44}$

Maria Helena Diniz exemplifica as situações que podem decorrer da fertilização humana assistida ${ }^{45}$ Destacamos aquelas atinentes à cessão temporária de útero, como:

a) fecundação de um óvulo da esposa ou companheira com esperma do marido ou convivente, transferindo-se o embrião para o útero de outra mulher;

b) fertilização in vitro com sêmen e óvulo de estranhos, por encomenda de um casal estéril, implantando-se o embrião no útero da outra;

c) fertilização, com esperma de terceiro, de óvulo da esposa ou convivente, implantando em útero de outra mulher.

A cessão temporária de útero rompe com paradigmas sociais da ideia tradicional de maternidade, paternidade e filiação a par-

43 VENOSA, Silvio de Salvo. Direito civil: direito de família. 2. ed. São Paulo: Atlas, 2002. p. 271.

44 VENOSA, Silvio de Salvo. Direito civil: direito de família. 2. ed. São Paulo: Atlas, 2002. p. 271.

45 DINIZ, Maria Helena. 0 estado atual do biodireito. 2. ed. São Paulo: Saraiva, 2002. p. 476. 
tir da participação temporária de uma pessoa alheia à relação na formação familiar e que se desvincula totalmente após o parto.

A partir do próprio conceito de cessão temporária do útero já podemos perceber a complexidade do tema frente às relações estabelecidas pelas partes e as dúvidas de natureza jurídica provenientes dessas relações demonstram a importância de um estudo pormenorizado do assunto.

\subsection{A RESOLUÇÃO DO cfm nำ 2.168/2017 E A CESSÃO TEM-} PORÁRIA DE ÚTERO NO BRASIL

Não há legislação brasileira específica sobre a cessão temporária de útero. Por isso, o Conselho Federal de Medicina (CFM) editou norma deontológica regulamentando a conduta dos médicos e estabelecendo os requisitos a serem observados nos procedimentos de reprodução humana assistida.

Desde o ano de 1992, o CFM vem editando resoluções sobre o assunto e atualmente vige a Resolução no 2.168/2017. Na exposição de motivos dessa Resolução, o Conselho menciona a lacuna legislativa:

No Brasil, até a presente data, não há legislação específica a respeito da reprodução assistida (RA). Tramitam no Congresso Nacional, há anos, diversos projetos a respeito do assunto, mas nenhum deles chegou a termo. ${ }^{46}$

Essa Resolução estabelece os requisitos para o uso da técnica de reprodução assistida relacionada à cessão temporária de útero, merecendo destaque:

a) existência de problema médico que impeça ou que contraindique a gestação na doadora genética;

46 CONSELHO FEDERAL DE MEDICINA (CFM). Resolução CFM no 2.168/2017. Disponível em <https://sistemas.cfm.org.br/normas/visualizar/resolucoes/ BR/2017/2168>. Acesso em: 12 mai. 2018. 
b) a cedente do útero precisa pertencer à família de um dos parceiros, com parentesco consanguíneo até o quarto grau;

c) inexistência de caráter lucrativo ou comercial;

d) assinatura das partes em termo de consentimento livre e esclarecido, mencionando os riscos envolvidos, os aspectos biopsicossociais e legais da filiação;

e) relatório médico psicológico, de maneira a atestar que os envolvidos tenham adequação clínica e emocional;

f) termo de compromisso livre e esclarecido, assinado pelos pacientes e a cedente do útero, contemplando aspectos legais da filiação;

g) compromisso das pacientes ao tratamento e acompanhamento médico, inclusive multidisciplinar, se necessário, à cedente do útero até o puerpério;

h) compromisso do registro civil da criança pelos pacientes;

i) apresentação de aprovação escrita do cônjuge ou companheiro, se a cedente for casada ou viver em união estável.

Além dos requisitos específicos para a cessão temporária de útero, mencionados anteriormente, a Resolução também estabelece princípios gerais a serem observados independentemente da técnica de reprodução assistida utilizada, tais como: o limite de idade de 50 anos às candidatas a gestação; a inexistência de risco grave para a saúde dos pacientes e a probabilidade de sucesso na utilização das técnicas; a obrigatoriedade do consentimento livre e esclarecido com a concordância escrita de todos os pacientes; a proibição de selecionar o sexo ou outra característica biológica da futura criança (exceto para evitar doença); a necessidade de que o paciente seja pessoa capaz.

É possível observarmos que o Conselho Federal de Medicina, além de regular a conduta ética dos médicos, também se preocupou com questões jurídicas, tanto para proteção dos médicos como dos pacientes. 
No entanto, é possível que ocorram situações que extrapolem o disposto na Resolução do CFM, como por exemplo, se a cedente do útero se recusasse a entregar a criança após o parto e se os pais, autores do projeto parental, quisessem desistir da criança após a realização do procedimento. Como essa situação ficaria juridicamente? Resta a dúvida se os termos de compromisso firmados pelas partes têm o condão de obrigar, coercivamente, as partes ao exato cumprimento do pactuado. Rompido o pacto haveria o direito a perdas e danos ${ }^{47}$

E se diante do desentendimento os casos fossem levados ao Poder Judiciário, como o litígio seria resolvido, considerando que o mesmo precisa se pronunciar mesmo diante da ausência legislativa ${ }^{48}$ ?

Por todo o exposto, depreendemos que o tema possui relevância social e que o estudo científico do instrumento jurídico utilizado na cessão temporária de útero tem um papel fundamental enquanto estivermos diante de lege ferenda que trate minuciosamente sobre o assunto.

\section{DOS DIREITOS FUNDAMENTAIS ENVOLVIDOS}

Diante das técnicas trazidas pela ciência, é essencial passarmos à análise da reprodução humana assistida frente aos princípios e direitos fundamentais que alicerçam o biodireito no

47 DINIZ, Maria Helena. 0 estado atual do biodireito. 2. ed. São Paulo: Saraiva, 2002. p. 506-508.

48 Art. 140 do Código de Processo Civil: "O juiz não se exime de decidir sob a alegação de lacuna ou obscuridade do ordenamento jurídico." BRASIL. Lei no 13.105 de 16 de março de 2015 [Código de Processo Civil]. Disponível em: < http://www.planalto.gov.br/ccivil_03/_ato2015-2018/2015/lei/ 113105.htm>. Acesso em: 13 mai. 2018.

Art. 4ํ da Lei de Introdução às normas do Direito Brasileiro: "Quando a lei for omissa, o juiz decidirá o caso de acordo com a analogia, os costumes e os princípios gerais de direito." BRASIL. Decreto-lei no 4.657 de 04 de setembro de 1942 [Lei de Introdução às normas do Direito Brasileiro]. Disponível em: < http://www.planalto.gov.br/ccivil_03/decreto-lei/Del4657compilado.htm>. Acesso em: 13 mai. 2018. 
ordenamento jurídico brasileiro de forma a verificar a possibilidade, ou não, de aderência e limitação à utilização dos mesmos.

\subsection{DIGNIDADE DA PESSOA HUMANA}

0 princípio ${ }^{49}$ da dignidade da pessoa humana, também conhecido como valor fundamental, está presente expressamente no preâmbulo da Declaração Universal dos Direitos Humanos ${ }^{50}$ e na Constituição Federal brasileira de 1988, no artigo 1ํ, inciso III ${ }^{51}$, como fundamento da República, como ordem jurídica, política, social, econômica e cultural. ${ }^{52}$

A dignidade da pessoa humana não integra o rol dos direitos fundamentais da ordem jurídica, pois é o alicerce que os fundamenta, uma qualidade intrínseca que possuem. Proclamar a primazia da dignidade humana como princípio fundamental do Estado significa reconhecê-la como atributo de um e de todos, inserindo o ser humano no centro da ordem jurídica. ${ }^{53}$

Fiuza e Hryniewicz relembram a máxima kantiana que dizia que a humanidade deveria ser tratada tanto na sua própria pessoa como na do outro, como um fim e não como um meio, reconhecendo o outro como alteridade e centro de dignidade. ${ }^{54}$

0 Estado vinculou-se ao dever de prover a proteção da

49 ALEXY, Robert. Teoria dos Direitos Fundamentais. Trad. Virgílio A. Silva. São Paulo: Malheiros, 2008. p. 117. Segundo o autor, princípios são mandamentos de otimização em face de possibilidades jurídicas e fáticas.

50 Declaração Universal dos Direitos Humanos. Assembleia Geral das Nações Unidas em Paris. 10 dez. 1948. Disponível em: < https://www.ohchr.org/EN/ UDHR/Documents/UDHR_Translations/por.pdf>. Acesso em: 01 out. 2018.

51 Presente também no artigo 170 , caput, artigo 226, $\S 7^{\circ}$, artigo 227 , caput, bem como implicitamente em outros dispositivos constitucionais.

52 GAMA, Guilherme Calmon Nogueira da. A nova filiação: o biodireito e as relações parentais: o estabelecimento da parentalidade-filiação e os efeitos jurídicos da reprodução assistida heteróloga. Rio de Janeiro: Renovar, 2003. p. 131.

53 GODINHO, Adriano Marteleto. Direito ao próprio corpo: direitos da personalidade e os atos de limitação voluntária. Curitiba: Juruá, 2015. p. 40-41.

54 SAUWEN, Regina Fiuza; HRYNIEWICZ, Severo. 0 Direito “in vitro” da bioética ao biodireito. 3. ed. Rio de Janeiro: Lumen Juris, 2008. p. 58. 
dignidade contra a intervenção de particulares e de qualquer entidade que tente violá-la. Sarlet apresenta um conceito de dignidade humana que abrange sua dimensão universal e natureza de cláusula aberta:

\begin{abstract}
Temos por dignidade da pessoa humana a qualidade intrínseca e distintiva de cada ser humano que o faz merecedor do mesmo respeito e consideração por parte do Estado e da comunidade, implicando, neste sentido, um complexo de direitos e deveres fundamentais que asseguram a pessoa tanto contra todo e qualquer ato de cunho degradante e desumano, como venham a lhe garantir as condições existenciais mínimas para uma vida saudável, além de propiciar e promover sua participação ativa e co-responsável nos destinos da própria existência e da vida em comunhão com os demais seres humanos. ${ }^{55}$
\end{abstract}

A dignidade da pessoa humana apresenta duas projeções: de um lado a dignidade confere autonomia, liberdade de agir e decidir, por outro, restrição da própria liberdade diante do risco de violação que comprometa a dignidade do próprio titular. ${ }^{56}$ Nesse sentido, diz-se que opera ao mesmo tempo como mola propulsora e freio da autonomia privada. ${ }^{57}$

O progresso da ciência está associado ao valor da pessoa humana, pois a própria razão da ciência é a vida humana. ${ }^{58} 0 \mathrm{~s}$

55 SARLET, Ingo Wolfgang. Dignidade da pessoa humana e direitos fundamentais na Constituição Federal de 1988. Porto Alegre: Livraria do Advogado, 2008. p. 63.

56 GODINHO, Adriano Marteleto. Direito ao próprio corpo: direitos da personalidade e os atos de limitação voluntária. Curitiba: Juruá, 2015. p. 49.

57 GODINHO, Adriano Marteleto. Direito ao próprio corpo: direitos da personalidade e os atos de limitação voluntária. Curitiba: Juruá, 2015. p. 184.

58 GAMA, Guilherme Calmon Nogueira da. A nova filiação: o biodireito e as relações parentais: o estabelecimento da parentalidade-filiação e os efeitos jurídicos da reprodução assistida heteróloga. Rio de Janeiro: Renovar, 2003. p. 35. 
avanços científicos permitiram à pessoa humana intervir na função reprodutora do organismo humano, extrapolando o funcionamento de seu próprio corpo. ${ }^{59}$ Daí a necessidade de se harmonizar a dignidade da pessoa humana ao progresso científico.

As discussões jurídicas sobre a reprodução humana assistida giram no entorno da possibilidade ou não do Estado em reduzir a autonomia privada de maneira a impedir que o corpo represente para o homem um mero objeto, uma "coisificação" da pessoa. ${ }^{60}$ Os temas ligados à bioética ${ }^{61}$ impulsionam uma rediscussão dos parâmetros do direito, quando colocam em xeque eventuais conflitos com a dignidade de pessoa humana, capazes de comprometer, por exemplo, a geração atual e as gerações futuras. ${ }^{62}$

Há controvérsias se existe, ou não, um caráter absoluto da dignidade da pessoa humana, se é permitida, ou não, a sua relativização em determinados casos. Gama defende a posição de que não há absoluta intangibilidade, mas que o princípio possui um núcleo essencial intangível, que veda o tratamento desumano e degradante como objeto de proteção e moralidade universal. ${ }^{63}$

59 GAMA, Guilherme Calmon Nogueira da. A nova filiação: o biodireito e as relações parentais: o estabelecimento da parentalidade-filiação e os efeitos jurídicos da reprodução assistida heteróloga. Rio de Janeiro: Renovar, 2003. p. 88.

60 GODINHO, Adriano Marteleto. Direito ao próprio corpo: direitos da personalidade e os atos de limitação voluntária. Curitiba: Juruá, 2015. p. 194.

61 LIMA NETO, Francisco Vieira. A maternidade de substituição e o contrato de gestação por outrem. In: SANTOS, Maria Celeste Cordeiro Leite (Org). Biodireito: ciência da vida, os novos desafios. São Paulo: Revista dos Tribunais, 2001. p. 121 . O autor conceitua a bioética por "disciplina que examina e discute os aspectos éticos relacionados com o desenvolvimento $e$ as aplicações da biologia e da medicina, indicando os caminhos e o modo de se respeitar o valor da pessoa humana, como unidade e como um todo".

62 LEITE, Eduardo de Oliveira (Coord). Grandes temas da atualidade: bioética e biodireito. Rio de Janeiro: Forense, 2004. p. 338.

63 GAMA, Guilherme Calmon Nogueira da. A nova filiação: o biodireito e as relações parentais: o estabelecimento da parentalidade-filiação e os efeitos jurídicos da reprodução assistida heteróloga. Rio de Janeiro: Renovar, 2003. p. 136. 
A dignidade humana é assegurada a partir da tutela de outros bens jurídicos que a ela estão vinculados, como a vida, a integridade física, a intimidade, em diferentes graus ${ }^{64}$, e que remontam a proteção e o desenvolvimento de todas as pessoas. ${ }^{65}$ 0 biodireito busca o fundamento de validade das regras jurídicas de comportamento no princípio da dignidade humana e nos direitos fundamentais previstos. ${ }^{66}$

\subsection{DIREITO À VIDA}

Logicamente, a vida está inteiramente relacionada ao princípio da dignidade da pessoa humana, merecendo ser construída e desenvolvida com respeito, promoção e proteção e que a todos condiciona ${ }^{67}$ No biodireito está relacionado também à defesa da vida física e da qualidade de vida.

0 direito à vida é o mais fundamental de todos os demais direitos por ser um pré-requisito aos demais direitos, é pressuposto para usufruir dos demais. A Constituição Federal garantiu a todos a inviolabilidade do direito à vida no artigo $5^{\circ}$, caput, cabendo ao Estado assegurá-la duplamente, através do direito do indivíduo de continuar vivo e de ter vida digna quanto subsistência. ${ }^{68}$ Pri-

64 GAMA, Guilherme Calmon Nogueira da. A nova filiação: o biodireito e as relações parentais: o estabelecimento da parentalidade-filiação e os efeitos jurídicos da reprodução assistida heteróloga. Rio de Janeiro: Renovar, 2003. p. 137.

65 SARLET, Ingo Wolfgang. Dignidade da pessoa humana e direitos fundamentais na Constituição Federal de 1988. Porto Alegre: Livraria do Advogado, 2008. p. 155.

66 GAMA, Guilherme Calmon Nogueira da. A nova filiação: o biodireito e as relações parentais: o estabelecimento da parentalidade-filiação e os efeitos jurídicos da reprodução assistida heteróloga. Rio de Janeiro: Renovar, 2003. p. 161.

67 GAMA, Guilherme Calmon Nogueira da. A nova filiação: o biodireito e as relações parentais: o estabelecimento da parentalidade-filiação e os efeitos jurídicos da reprodução assistida heteróloga. Rio de Janeiro: Renovar, 2003. p.162.

68 MORAES, Alexandre de. Direito Constitucional. 32. ed. São Paulo: Atlas, 2016. p. 97. 
meiro, assegurando o direito da pessoa estar e permanecer viva, através da garantia que sua existência física não será violada pelo Estado e por particulares. Segundo, através de proteção da vida digna com acesso a bens e serviços essenciais. ${ }^{69}$

A carta constitucional foi imprecisa ao silenciar sobre o início da vida humana para fins de proteção jurídica. Cumpre salientar que a vida uterina também é objeto de proteção para sua continuidade fisiológica, tendo o feto como ser individualizado, com carga genética própria, sendo incorreto dizer que a vida do feto está englobada pela da gestante. ${ }^{70}$

Assim como nos demais direitos, é possível uma relativização do direito à vida, comportando diferentes graduações como nos casos de pena de morte na guerra declarada, aborto ético ou humanitário. ${ }^{71}$

\subsection{AUTONOMIA PRIVADA}

Segundo Alexy "o conceito de liberdade é, ao mesmo tempo, um dos conceitos práticos mais fundamentais e menos claros". ${ }^{72}$ Para o autor, toda a liberdade existe ao menos em relação ao Estado, garantida por um direito a que o Estado não "embarace" o titular para aquilo que é constitucionalmente livre. ${ }^{73}$

A liberdade constitui um dos valores essenciais à ordem jurídica fundada na democracia. Da mesma forma que os direitos anteriores, há uma relação estreita entre o direito à liberdade, ligada à autonomia da pessoa humana, e ao princípio da digni-

69 MASSON, Nathalia. Manual de Direito Constitucional. 4. ed. Salvador: Juspodivm, 2016. p. 213.

70 MORAES, Alexandre de. Direito Constitucional. 32. ed. São Paulo: Atlas, 2016. p. 98.

71 MORAES, Alexandre de. Direito Constitucional. 32. ed. São Paulo: Atlas, 2016. p. 98.

72 ALEXY, Robert. Teoria dos Direitos Fundamentais. Trad. Virgílio A. Silva. São Paulo: Malheiros, 2008. p. 218.

73 ALEXY, Robert. Teoria dos Direitos Fundamentais. Trad. Virgílio A. Silva. São Paulo: Malheiros, 2008. p. 234. 
dade humana, por se tratar de valor inalienável e indispensável à promoção da vida. ${ }^{74}$

Também, a liberdade está relacionada às discussões de temas da bioética, no empregado das técnicas de reprodução, pois possui vínculo estreito com a responsabilidade no conjunto de direitos e deveres relacionados. ${ }^{75}$

A liberdade está expressa no preâmbulo do texto constitucional e no seu artigo $5^{\circ}$, caput, bem como no artigo $3^{\circ}$, inciso I e artigo 5o, inciso II (atrelado ao princípio da legalidade). No âmbito privado é utilizada, em sede de obrigações e contratos, como uma faculdade das pessoas em se vincularem juridicamente, através da manifestação da vontade. Conforme Godinho "a autonomia exprime a noção de que às pessoas se confere a liberdade de se ditarem as próprias regras", desde que não contrárias à lei e à ordem pública. ${ }^{76}$

A vontade humana declarada livremente possui força de lei entre as partes, conhecida pela expressão "pacta sunt servanda" e que encontra limites nas repercussões sociais que emanam do negócio, conforme previsão do artigo 421 do Código Civil. ${ }^{77} \mathrm{~A}$ autonomia privada consiste, portanto, na liberdade de agir juridicamente, dentro da imposição de determinados limites contidos em princípios e regras que conformam o querer individual num plano axiológico. ${ }^{78}$

74 GODINHO, Adriano Marteleto. Direito ao próprio corpo: direitos da personalidade e os atos de limitação voluntária. Curitiba: Juruá, 2015. p. 91-92.

75 GAMA, Guilherme Calmon Nogueira da. A nova filiação: o biodireito e as relações parentais: o estabelecimento da parentalidade-filiação e os efeitos jurídicos da reprodução assistida heteróloga. Rio de Janeiro: Renovar, 2003. p. 172.

76 GODINHO, Adriano Marteleto. Direito ao próprio corpo: direitos da personalidade e os atos de limitação voluntária. Curitiba: Juruá, 2015. p. 92.

77 GODINHO, Adriano Marteleto. Direito ao próprio corpo: direitos da personalidade e os atos de limitação voluntária. Curitiba: Juruá, 2015. p. 95-96.

78 GODINHO, Adriano Marteleto. Direito ao próprio corpo: direitos da personalidade e os atos de limitação voluntária. Curitiba: Juruá, 2015. p. 97. 
A autonomia é uma característica da própria natureza humana:

A autonomia para as escolhas que pautam a existência de uma pessoa, mormente no âmbito dos direitos de personalidade e da bioética, em geral, e da disponibilidade do próprio corpo, em particular, é um meio de se preservar a identidade de cada indivíduo, que vive em torno dos seus princípios: não se pode negá-los sem negar a si mesmo. ${ }^{79}$

A informação é essencial para garantia da autonomia pessoal e assim permitir a liberdade consciente de escolha, por isso o artigo $5^{\circ}, \mathrm{XIV}$, da CF assegura o direito à informação. ${ }^{80}$

Os regramentos em torno da reprodução humana assistida têm atrelado a autorização desses procedimentos pelo paciente (e do companheiro (a)) ao termo de consentimento, livre e esclarecido, que consiste, portanto, na manifestação da autonomia privada de aquiescência diante do recebimento de informações pelo médico sobre os riscos envolvidos, conforme disciplina o artigo 15 do Código Civil.

\subsection{DIREITO AO PRÓPRIO CORPO}

Atrelado aos direitos fundamentais de personalidade está o direito ao próprio corpo, não patrimonial, mas pessoal. Gama entende que o corpo representa a perspectiva privatística do direito fundamental à integridade física. ${ }^{81}$ Esse direito se configura

79 OLIVEIRA, Nuno Manuel Pinto apud GODINHO, Adriano Marteleto. Direito ao próprio corpo: direitos da personalidade e os atos de limitação voluntária. Curitiba: Juruá, 2015. p. 100.

80 ALMEIDA, Aline Mignon de. Bioética e biodireito. Rio de Janeiro: Lumen Juris, 2000. p. 20.

81 GAMA, Guilherme Calmon Nogueira da. A nova filiação: o biodireito e as relações parentais: o estabelecimento da parentalidade-filiação e os efeitos jurídicos da reprodução assistida heteróloga. Rio de Janeiro: Renovar, 2003. p. 166. 
na disposição de suas partes, em vida ou para depois da morte, com finalidades científicas ou humanitárias ${ }^{82}$, por isso carece de análise diante dos avanços biotecnológicos de interferência no corpo da pessoa humana, que envolve a disposição de certas partes do corpo humano, como no transplante de órgãos e na inseminação artificial.

0 direito ao próprio corpo pode ser observado em dispositivos constitucionais esparsos como no artigo 5ํㅜ , incisos III, XLVII e XLIX, da Constituição Federal, entre outros. A Constituição brasileira, no artigo 199, §4ํㅡㄹ atribuiu à lei complementar ${ }^{83}$ as condições de limitação da disposição de partes do corpo, vedando todo tipo de comercialização. ${ }^{84}$ Essa lei, no artigo 9으, §3ํㅡ, refere que a doação somente pode ter por objeto órgãos duplos ou partes de órgãos, tecidos ou partes do corpo que não impliquem em risco ao organismo do doador, nem comprometam suas aptidões. ${ }^{85}$

A pessoa não possui um direito real sobre as partes do seu corpo, necessitando que a ordem jurídica regule expressamente as condições para seu exercício, limitando o direito, preservando a sobrevivência digna, afastando o corpo humano da condição de coisa. $^{86}$

82 PEREIRA, Caio Mário da Silva Pereira. Instituições de direito civil: introdução ao Direito Civil. 21. ed. Rio de Janeiro: Forense, 2006. v.1. p. 250.

83 BRASIL. Lei no 9.434 de 4 de fevereiro de 1997 [Dispõe sobre a remoção de órgãos, tecidos e partes do corpo humano para fins de transplante e tratamento e dá outras providências]. Disponível em:< http://www.planalto. gov.br/cciViL 03/LEIS/L9434.htm>. Acesso em: 25 set. 2018. Esse diploma refere que não estão compreendidos entre os tecidos o sangue, esperma e óvulo.

84 BRASIL. Constituição (1988). Constituição da República Federativa do

Brasil. Disponível em: < http://www.planalto.gov.br/ccivil 03/constituicao/ constituicao.htm>. Acesso em: 3 out. 2018.

85 VENOSA, Sílvio de Salvo. Direito Civil: parte geral. 12. ed. São Paulo: Atlas, 2012. v. 1. p. 187.

86 GAMA, Guilherme Calmon Nogueira da. A nova filiação: o biodireito e as relações parentais: o estabelecimento da parentalidade-filiação e os efeitos jurídicos da reprodução assistida heteróloga. Rio de Janeiro: Renovar, 2003. p. 168-169. 
Silva destaca que a evolução dos direitos sociais deu a cada indivíduo a obrigação de zelar pelo interesse comum: "o único tem o dever de resguardar os interesses do múltiplo e, inclusive, em uma análise mais profunda, o homem necessita preservar 0 próximo para que assim preserve a si mesmo." 87

Chaves salienta que a disponibilidade corporal carece de atenção do direito quando a pessoa a realiza em três situações: em seu benefício próprio com objetivo de recuperar e melhorar sua saúde, em benefício de terceiros determinados através de transplantes e em benefício próprio ou de terceiros indeterminados através de experimentação científica. ${ }^{88}$

A cessão de partes do corpo que se reconstituem naturalmente ou de outras não reconstituíveis são permitidas para fins terapêuticos e de transplantes (artigo 13, parágrafo único, Código Civil), desde que não prejudiquem a saúde do doador em observância à lei especial (Lei 9.4348/199789). ${ }^{90}$

Cabe destacar, também, a previsão legal de que os atos de disposição do corpo não devem contrariar os bons costumes (artigo 13, caput, Código Civil), ou seja, devem se valer de comportamento probo, socialmente aceito e que corresponda a ideia de moralidade mínima estabelecida em determinado tempo e lugar. ${ }^{91}$

O limite de disposição do corpo individual é estabelecido por uma barreira à autonomia privada, posta pelo pensamento

87 SILVA, Ivan de Oliveira. Biodireito, bioética e patrimônio genético brasileiro. São Paulo: Pillares, 2008. p. 111-112.

88 CHAVES, Antônio. Direito à vida e ao próprio corpo: intersexualidade, transexualidade, transplantes. 2. Ed. São Paulo: Revista dos Tribunais, 1994. p. 87.

89 BRASIL. Lei no 9.434 de 4 de fevereiro de 1997 [Dispõe sobre a remoção de órgãos, tecidos e partes do corpo humano para fins de transplante e tratamento e dá outras providências]. Disponível em: $<$ http://www.planalto. gov.br/cciViL 03/LEIS/L9434.htm>. Acesso em: 25 set. 2018.

90 PEREIRA, Caio Mário da Silva Pereira. Instituições de direito civil: introdução ao Direito Civil. 21. ed. Rio de Janeiro: Forense, 2006. v.1. p. 252.

91 GODINHO, Adriano Marteleto. Direito ao próprio corpo: direitos da personalidade e os atos de limitação voluntária. Curitiba: Juruá, 2015. p. 234. 
coletivo, de conteúdo ético e existencial, que foi recepcionada pelo direito, sobretudo quando se pretenda dispor da integridade física com risco à própria vida.

\subsection{DIREITO AO PLANEJAMENTO FAMILIAR E À REPRODUÇÃO}

0 direito ao planejamento familiar é um direito humano básico reconhecido pela Organização das Nações Unidas -ONU ${ }^{92}$ e presente na legislação brasileira. ${ }^{93}$ A Constituição da República Federativa do Brasil, 1988, considera a família a base da sociedade (artigo 226, caput) e em seu artigo 226, § 7으, trouxe o amparo ao planejamento familiar, fundado nos princípios de dignidade humana e na paternidade responsável. Através desse dispositivo compete ao Estado a obrigação preventiva de dar informação às pessoas para que decidam, em sua privacidade, o número de filhos e o espaçamento entre eles, bem como promocional, através de políticas e programas estatais de acesso aos métodos e mecanismos de planejamento familiar para que façam sua livre escolha. ${ }^{94}$

Nesse sentido, a Lei Federal no $9.263 / 96^{95}$ foi criada para regular o $§ 7^{\circ}$ do artigo 226 da Constituição Federal, cabendo salientar entre as disposições a proibição de ações de controle

92 Artigo 16 da Declaração universal dos direitos humanos.

Declaração Universal dos Direitos Humanos. Assembleia Geral das Nações Unidas em Paris. 10 dez. 1948. Disponível em: < https://www.ohchr.org/ EN/UDHR/Documents/UDHR Translations/por.pdf>. Acesso em: 01 out. 2018.

93 DINIZ, Maria Helena. 0 estado atual do biodireito. 2. ed. São Paulo: Saraiva, 2002. p. 137.

94 GAMA, Guilherme Calmon Nogueira da. A nova filiação: o biodireito e as relações parentais: o estabelecimento da parentalidade-filiação e os efeitos jurídicos da reprodução assistida heteróloga. Rio de Janeiro: Renovar, 2003. p. 444.

95 BRASIL. Lei no 9.263 de 12 de janeiro de 1996. Regula o §7ํㅡ do art. 226 da Constituição Federal, que trata do planejamento familiar, estabelece penalidades e dá outras providências. Disponível em: <http://www.planalto. gov.br/ccivil_03/leis/19263.htm>. Acesso em: 13 mai. 2018. 
demográfico (art. 2º , parágrafo único, da Lei 9.263/96) e a utilização, por todos, aos métodos e técnicas de concepção e contracepção cientificamente aceitos (art. 9ō, da Lei 9.263/96). Por esse dispositivo conclui-se que as técnicas de reprodução assistida são alcançadas por essa lei, levando a constatação que o direito brasileiro admite o uso das técnicas como direitos reprodutivos. ${ }^{96}$

0 direito ao planejamento familiar encontra limitações na dignidade da pessoa humana, na paternidade responsável e no melhor interesse da futura criança. ${ }^{97}$ Ao reconhecer os direitos à procriação devemos considerar os direitos fundamentais do filho. ${ }^{98}$

0 Código Civil Brasileiro de $2002^{99}$ tratou, timidamente, da inseminação artificial apenas no que diz respeito à questão da filiação. Para o doutrinador Silvio Venosa "o Código de 2002 não autoriza nem regulamenta a reprodução assistida, mas apenas constata a existência da problemática e procura dar solução ao aspecto da paternidade". ${ }^{100}$

0 planejamento familiar está relacionado à noção de direitos reprodutivos, ao livre exercício da sexualidade e da reprodução humana. ${ }^{101}$ Os artigos 196, 201 e 203 da Constituição Federal

96 BARBOZA, Heloisa Helena. Reprodução assistida e o novo Código Civil. In: SÁ, Maria de Fátima Freire de; NAVES, Bruno Torquato de Oliveira (Org). Bioética, biodireito e o novo Código Civil de 2002. Belo Horizonte: Del Rey, 2004. p. 230.

97 GAMA, Guilherme Calmon Nogueira da. A nova filiação: o biodireito e as relações parentais: o estabelecimento da parentalidade-filiação e os efeitos jurídicos da reprodução assistida heteróloga. Rio de Janeiro: Renovar, 2003. p. 450.

98 LEITE, Eduardo de Oliveira (Coord). Grandes temas da atualidade: bioética e biodireito. Rio de Janeiro: Forense, 2004. p. 159.

99 BRASIL. Lei no 10.406 de 10 de janeiro de 2002 [Código Civil Brasileiro]. Disponível em: < http://www.planalto.gov.br/CCivil_03/Leis/2002/L10406. htm>. Acesso em: 13 mai. 2018.

100 VENOSA, Silvio de Salvo. Direito civil: direito de família. 2. ed. São Paulo: Atlas, 2002. p. 268.

101 GAMA, Guilherme Calmon Nogueira da. A nova filiação: o biodireito e as relações parentais: o estabelecimento da parentalidade-filiação e os efeitos jurídicos da reprodução assistida heteróloga. Rio de Janeiro: Renovar, 2003. p. 444. 
asseguram a proteção à saúde, à gravidez, à maternidade que trazem à tona os direitos reprodutivos.

0 direito de procriar possui um conteúdo negativo, ao proteger o indíviduo de qualquer limitação perante o Estado permitindo a livre escolha entre procriar ou não, e um conteúdo positivo, de desenvolver a função de genitor. ${ }^{102}$ Compreende sobretudo o fator genético de dar origem ao filho que derive do próprio patrimônio genético. ${ }^{103}$

$\mathrm{Na}$ discussão sobre os direitos sexuais e reprodutivos em âmbito internacional, cabe destacar duas conferências promovidas pela ONU por serem consideradas marcos históricos sobre a afirmação dos direitos reprodutivos como direitos humanos e fundamentais e instituindo-os como base para as políticas públicas ${ }^{104}$ : Conferência Internacional sobre a População e Desenvolvimento (CIPD) ${ }^{105}$ realizada em 1994, no Cairo, que versou sobre direitos sexuais e reprodutivos, atribuindo "autonomia reprodutiva" e abrangendo a escolha quanto às técnicas de reprodução e a IV Conferência Mundial sobre a Mulher ${ }^{106}$, realizada em 1995, em

102 BARBOZA, Heloisa Helena. Reprodução assistida e o novo Código Civil. In: SÁ, Maria de Fátima Freire de; NAVES, Bruno Torquato de Oliveira (Org). Bioética, biodireito e o novo Código Civil de 2002. Belo Horizonte: Del Rey, 2004. P .228.

103 BARBOZA, Heloisa Helena. Reprodução assistida e o novo Código Civil. In: SÁ, Maria de Fátima Freire de; NAVES, Bruno Torquato de Oliveira (Org). Bioética, biodireito e o novo Código Civil de 2002. Belo Horizonte: Del Rey, 2004. p. 228.

104 BARBOZA, Heloisa Helena. Reprodução assistida e o novo Código Civil. In: SÁ, Maria de Fátima Freire de; NAVES, Bruno Torquato de Oliveira (Org). Bioética, biodireito e o novo Código Civil de 2002. Belo Horizonte: Del Rey, 2004. p. 229.

105 PATRIOTA, Tania. Relatório da Conferência Internacional sobre a População e Desenvolvimento: Plataforma de Cairo. [entre 1995 e 2005]. Disponível em: http://www.unfpa.org.br/Arquivos/relatorio-cairo.pdf. Acesso em: 04 out. 2018.

106 VIOTTI, Maria Luiza Ribeiro. Declaração e plataforma de ação da IV Conferência Mundial sobre a mulher: Pequim. [entre 1995 e 2005]. Disponível em http://www.unfpa.org.br/Arquivos/declaracao beijing.pdf. Acesso em: 04 out. 2018. 
Pequim, que reafirmou os direitos sexuais e reprodutivos como Direitos Humanos.

0 entendimento no plano internacional é o de que o acesso aos métodos de concepção e contracepção devem fazer parte de uma política que promova a liberdade de escolha individual, com fundamento ético e jurídico pautado na dignidade da pessoa humana. ${ }^{107}$

O exercício dos direitos reprodutivos não é absoluto, apresentando limites ao indivíduo, impondo o dever de considerar as necessidades dos filhos nascidos e por nascer, em harmonia com o bem comum. ${ }^{108}$

Conforme o estudo acima se verifica a relevância e pertinência da compreensão dos direitos fundamentais e da proteção dada pelo ordenamento jurídico à dignidade da pessoa humana. Entretanto, é possível concluir que todos os direitos fundamentais citados são passíveis de ponderação, admitindo a relativização.

\section{DO CONTRATO DE CESSÃO TEMPORÁRIA DE ÚTERO}

Após o estudo dos direitos fundamentais, carece análise sobre o instrumento jurídico adequado para perfectibilização, no mundo jurídico, dos atos relacionados à reprodução humana assistida, em especial, a cessão temporária de útero.

Nos casos de cessão temporária de útero é firmado um acordo para que uma mulher fértil (portadora) conceba, em seu útero, o filho de outra (mãe civil, genética ou socioafetiva). Quanto ao material genético utilizado há duas possibilidades: o embrião implantado na portadora foi fecundado com o material genético do casal interessado na procriação; embrião implantado na portadora foi fecundado com material alheio ao casal interessado na procriação. ${ }^{109}$

107 VENTURA, Miriam. Direitos Reprodutivos no Brasil. 3. ed. Brasília:\{s.n.\}, 2009. p. 87.

108 DINIZ, Maria Helena. 0 estado atual do biodireito. 2. ed. São Paulo: Saraiva, 2002. p. 136.

109 GODINHO, Adriano Marteleto. Direito ao próprio corpo: direitos da personalidade e os atos de limitação voluntária. Curitiba: Juruá, 2015. p. 254-255. 
Diante da ausência de legislação brasileira própria, discute-se a validade do acordo frente aos princípios e direitos constitucionais, às normas de direito civil e a cláusula geral de bons costumes. ${ }^{110}$

A doutrina se divide quanto às posições favoráveis e contrárias ao contrato, bem como à remuneração, merecendo análise os argumentos de ambas as correntes.

\subsection{DO CONTRATO DE GESTAÇÃO GRATUITA}

No Brasil, a Resolução do CFM no 2.168/2017 exige para acesso às técnicas de reprodução humana assistida a gratuidade, além da existência de um problema médico ou que se trate de união homoafetiva.

0 acordo em que uma mulher empresta seu útero para o desejo de um casal em ter filhos é visto de forma mais amistosa pela sociedade em geral do que aquele oneroso, sendo reconhecido judicialmente nos Estados Unidos (alguns estados) e Inglaterra.

Nesse sentido é o entendimento de alguns doutrinadores que se coadunam com a possibilidade de gestação substitutiva, desde que gratuita.

Venosa entende que a "fecundação em ventre alheio somente deverá ser admitida, em ultima ratio, por motivos de solidariedade e afeto, da mesma forma que a doação de esperma" ${ }^{111}$, ou seja, admite a modalidade gratuita.

Godinho entende pela possibilidade gratuita do procedimento com intuito de solucionar problemas de infertilidade, em decorrência do princípio da isonomia, assegurado pelo art. 5o da Constituição da República, e por "não violar nenhuma norma ou princípio jurídico contido no ordenamento brasileiro. ${ }^{112}$

110 GODINHO, Adriano Marteleto. Direito ao próprio corpo: direitos da personalidade e os atos de limitação voluntária. Curitiba: Juruá, 2015. p. 255.

111 VENOSA, Sílvio de Salvo. Direito Civil: direito de família. 12. ed. São Paulo: Atlas, 2012. v. 6. p. 243.

112 GODINHO, Adriano Marteleto. Direito ao próprio corpo: direitos da personalidade e os atos de limitação voluntária. Curitiba: Juruá, 2015. p. 257-258. 
Lima Neto adota como termo mais adequado o "pacto de gestação de substituição" diante da inexistência de valor econômico para a validade da avença. Conclui que no Brasil o pacto não fere a moral e os bons costumes se feito de forma gratuita diante de problemas de infertilidade da mulher portadora do material genético. ${ }^{113}$

Leite considera acertada a Resolução do CFM por inexistir direito constitucional capaz de proibir o recurso. Entende pertinente que inexista compensação pecuniária no procedimento e que o mesmo seja realizado em face de um vínculo familiar entre as partes e de problema médico que impeça a gestação. ${ }^{114}$

No entanto, há doutrinadores que inadmitem a adoção do procedimento, mesmo que gratuito. Aguiar entende que mesmo se não houver contraprestação pecuniária os motivos não seriam suficientes a ensejar a garantia de validade do negócio jurídico. Opina também pela impossibilidade de conversão do negócio jurídico, artigo 184 do Código Civil, quando extirpada a cláusula de pagamento, pois mesmo assim entende que continuaria inválido o contrato por versar sobre a entrega de um ser humano e atingir a dignidade da pessoa humana. ${ }^{115}$ Argumenta estar fora da autonomia da vontade a realização de negócio jurídico cujo objeto seja de indisponibilidade absoluta. ${ }^{116}$

Diniz entende que mesmo no contrato gratuito de gestação haveria a possibilidade de a gestante arrepender-se, recusar-se

113 LIMA NETO, Francisco Vieira. A maternidade de substituição e o contrato de gestação por outrem. In: SANTOS, Maria Celeste Cordeiro Leite (Org). Biodireito: ciência da vida, os novos desafios. São Paulo: Revista dos Tribunais, 2001. p. 140.

114 LEITE, Eduardo de Oliveira. Procriações artificiais e o direito: aspectos médicos, religiosos, psicológicos, éticos e jurídicos. São Paulo: Revista dos Tribunais, 1995. p. 411-412.

115 AGUIAR, Mônica. Direito à filiação e bioética. Rio de Janeiro: Forense, 2005. p. 111.

116 AGUIAR, Mônica. Direito à filiação e bioética. Rio de Janeiro: Forense, 2005. p. 159. 
à entrega da criança e até mesmo tentar o aborto, sendo imprescindível a vedação da técnica no país ou sua limitação rigorosa. ${ }^{117}$

Deste modo, verificamos que a cessão gratuita é vista como um ato de generosidade, afeto e altruísmo por alguns doutrinadores, sendo admitida a celebração do contrato firmado diante da impossibilidade natural de gestar. Ainda assim, encontramos correntes contrárias, que concluem pela invalidade jurídica do contrato mesmo que gratuito.

\subsection{DO CONTRATO DE GESTAÇÃO ONEROSA}

Em que pese não admitida pelo CFM, entende-se esse contrato quando existir contraprestação pecuniária do autor do projeto parental à gestante substitutiva. Sobre o contrato de gestação substitutiva onerosa Sauwen ${ }^{118}$ apresenta argumentos contrários e favoráveis à validade de tal contrato na esfera jurídica e ética, os quais serão contrapostos para permitir uma melhor análise.

a) "Coisificação" da pessoa: o argumento mais utilizado por aqueles que condenam esse tipo de contrato é o de que há uma reificação da pessoa, que seria tratada como objeto, pois o casal pagará um valor ao receber a criança, situação que feriria os princípios constitucionais ao violar o art.1ํㅡㄴ III. Afirmam que, sob o ponto de vista ético, haveria um atentado à dignidade e assim, à essência humana. Por outro lado, os adeptos à posição favorável entendem que não se trata de venda da criança, mas remuneração à gestante pelos serviços prestados, uma recompensa. Entendem que a remuneração realizada na entrega da criança, por si, não significa a compra de uma criança, mas o término da prestação de serviço. ${ }^{119}$

117 DINIZ, Maria Helena. 0 estado atual do biodireito. 2. ed. São Paulo: Saraiva, 2002. p. 508.

118 SAUWEN, Regina Fiuza; HRYNIEWICZ, Severo. O Direito “in vitro” da bioética ao biodireito. 3. ed. Rio de Janeiro: Lumen Juris, 2008. p.107-109.

119 AGUIAR, Mônica. Direito à filiação e bioética. Rio de Janeiro: Forense, 2005. p. 109. 
b) "Indústria" de bebês e exploração da mulher: outro argumento contrário a esse contrato refere que a prática criaria uma "indústria", um mercado de oferta de bebês que zombaria da moral vigente. Há também o argumento de que os contratos implicariam na exploração de mulheres, principalmente as mais pobres e menos instruídas, que se exporiam diante da possibilidade de recebimento de dinheiro. Os defensores do contrato rebatem a ideia de exploração das mulheres ao afirmarem que as explorações da pobreza e da ignorância se dão em várias atividades do ser humano e que não seria possível atribuir a esse contrato tal afirmação.

c) Cuidados com a criança: um terceiro argumento invocado pelos contrários é o de que a portadora poderá não observar as prescrições médicas por estar interessada apenas na recompensa, resultando em doenças para a criança. Os favoráveis afirmam que a mulher que gera os filhos para si também pode deixar de manter os cuidados necessários à gestação.

d) Rejeição em caso de doença grave: os desfavoráveis entendem que, apesar de previsão contratual sobre o aceite do casal, no caso de uma doença grave, poderia existir uma rejeição quanto ao recebimento da criança, levando ao seu abandono. Os favoráveis entendem que há obrigação contratual de assumir a criança não poderá ser desfeita e que o "abandono" de criança é um fenômeno social, não devendo ser relacionado à gestação substitutiva.

e) Proibição à remuneração de órgãos: os contrários entendem que assim como na doação há vedação à remuneração, na gestação também não caberia remuneração. Os adeptos entendem que deve inexistir relação com a doação por se tratarem de situações diversas. 
A seguir, verificaremos o posicionamento de alguns doutrinadores contrários à contratação onerosa.

Aguiar posiciona-se pela ilicitude do contrato oneroso sob três enfoques ${ }^{120}$ :

1. Entende que o objeto seria a entrega da criança e não a ocorrência da gravidez, não devendo ser considerado um bem a serviço dos interesses dos genitores, apartado dos comandos do art. 1ํㅡ. III, art. 5o e art. 199, §4º da CF.

2. Salienta que se houvesse validade na contratação esta não seria compra e venda, principalmente quando o material biológico for fornecido pelo casal interessado na gestação, entendendo que não poderiam "comprar" o que já os pertence.

3. Esclarece que a possibilidade de validade do contrato não pode ser interpretada em analogia à adoção, pois na adoção o desfaziamento do laço biológico é feito judicialmente levando em consideração o melhor interesse da criança, enquanto que na gestação substitutiva a criança sequer existe previamente.

Diniz entende como injustificável qualquer contrato oneroso em que o casal alugue o ventre ou contrate a prestação de serviço de gestação. ${ }^{121}$ Entende que o procedimento deveria ser coibido diante dos riscos físicos e psíquicos para a criança e sua identidade, além do recrutamento de mulheres para fins de locação de útero, devendo o legislador regulá-la rigorosamente, se impossível for vedá-la. ${ }^{122}$

120 AGUIAR, Mônica. Direito à filiação e bioética. Rio de Janeiro: Forense, 2005. p. 109-110.

121 DINIZ, Maria Helena. 0 estado atual do biodireito. 2. ed. São Paulo: Saraiva, 2002.p.507.

122 DINIZ, Maria Helena. 0 estado atual do biodireito. 2. ed. São Paulo: Saraiva, 2002.p. 478. 
Pontes de Miranda entendia pela inexistência de negócio jurídico tendo por objeto o corpo ou partes do corpo antes de separadas. 0 autor trazia como exemplo doutrinário a venda de cabelos, conforme trecho a seguir:

A venda e compra ou promessa de compra e venda de cabelos ao cabeleireiro, ou ao fabricante de bonecas, entra no mundo jurídico porque é possível negócio jurídico sobre coisa futura, apenas, não produz efeito de obrigar a separar, nem indenizar, porque seria negócio jurídico ilícito: o negócio jurídico vale e produz efeito no que é promessa de prestar, se o promitente resolver separar, e.g., se cortar os cabelos. ${ }^{123}$

Venosa entende nulo o contrato oneroso porque imoral é o seu objeto, com a obrigação decorrente dele considerada obrigação natural. ${ }^{124}$

Ferraz afirma ser inviável admitir o contrato, bem como a remuneração, por entender que o objeto será a pessoa e, portanto, incompatível com a Constituição vigente. ${ }^{125}$

Silva sustenta a impossibilidade de contrato de cessão de útero pela ausência de um dos requisitos do Código Civil, objeto lícito, consoante o artigo $104 .{ }^{126}$

Godinho reforça a vedação à onerosidade do contrato por entender que não se admite que as partes do corpo humano sejam objetos de negócio como "meras coisas postas no comércio jurídico, como se daria com a compra e venda, a locação e a permuta, entre outros". ${ }^{127}$

123 MIRANDA, Pontes de. Atualizado por Vilson Rodrigues Alves. Tratado de Direito Privado: parte geral. Campinas: Bookseller, 2000. 2 v.p. 41-42.

124 VENOSA, Sílvio de Salvo. Direito Civil: direito de família. 12. ed. São Paulo: Atlas, 2012. v. 6.p.243.

125 FERRAZ, Sérgio. Manipulações biológicas e princípios constitucionais. Porto Alegre: Sete Mares, 1991.p. 56.

126 SILVA, Ivan de Oliveira. Biodireito, bioética e patrimônio genético brasileiro. São Paulo: Pillares, 2008.p. 81.

127 GODINHO, Adriano Marteleto. Direito ao próprio corpo: direitos da personalidade e os atos de limitação voluntária. Curitiba: Juruá, 2015.p.257. 
Maria Berenice Dias diz “a gestação por substituição seria um negócio jurídico de comportamento, compreendendo para a "mãe de aluguel" obrigações de fazer e não fazer, culminando com a obrigação de dar, consistente na entrega do filho". A avença seria nula, pois a criança não pode ser objeto de contrato devido a proibição de gestar o filho alheio mediante pagamento, pela ilicitude do objeto (art.104, II CC). Porém entende que, apesar das vedações legais, não haveria justificativa para negar a remuneração pelo serviço prestado. ${ }^{128}$

Entretanto, alguns doutrinadores entendem pela possibilidade de que a avença traga retribuição pecuniária à gestante substitutiva. Lagrasta aponta que o contrato deverá prever, além do aluguel pela prestação do serviço, a contratação de seguro de vida à gestante limitado pelo período de inserção do óvulo até o parto, com extensão a eventuais sequelas, resguardando-lhe a saúde e integridade. Afirma ainda, que as cláusulas devem proteger a parturiente e o nascituro, bem como prever a indenização que lhe for devida. ${ }^{129}$

Almeida se coaduna com a vertente da possibilidade do contrato ao referir que não é porque a remuneração é paga na entrega que há uma compra da criança: "o serviço se conclui com a entrega da criança que ficou no útero locado durante nove meses e por isso a remuneração é no momento da entrega". A remuneração deve conter despesas com alimentação e vestuário, assim como despesas médicas. Afirma que a obrigação da gestante é de meio, pois empregando todos os cuidados pertinentes, se a criança nascer morta, exime-se da responsabilidade. ${ }^{130}$

128 DIAS, Maria Berenice. Manual de Direito das famílias. 4.ed. São Paulo: Revista dos tribunais, 2016. p. 675.

129 LAGRASTA NETO, Caetano; TARTUCE, Flávio; SIMÃO, José Fernando. Direito de família: novas tendências e julgamentos emblemáticos. 2.ed. São Paulo: Atlas, 2012. p. 362.

130 ALMEIDA, Aline Mignon de. Bioética e biodireito. Rio de Janeiro: Lumen Juris, 2000. p. 50-52. 
Ida Luca entende que o embrião que está sendo gestado não será comercializado: "a participação da gestante de substituição no acordo refere-se a possibilidade que esse embrião se desenvolva. Não há qualquer violação em que haja uma retribuição a esta pela atividade prestada." ${ }^{31}$

Em suma, os doutrinadores contrários ao contrato de cessão onerosa de útero entendem que nesse tipo de contrato haveria uma disponibilidade da vida humana, um comércio da dignidade e que, portanto, resultante na ilicitude do objeto a ser contratado. ${ }^{132}$ Já os favoráveis ao contrato entendem que não há violação da dignidade da pessoa humana, por não se tratar de comércio da criança, mas de uma prestação de serviço pela gestante e de cabível compensação pecuniária.

Ainda que a avença não seja admitida com unanimidade pela doutrina, o procedimento vem sendo realizado no Brasil, em consonância com a Resolução do CFM. Por esse motivo, faz-se necessária a reflexão sobre a filiação das crianças nascidas por meio das técnicas de reprodução assistida frente às disposições do Código Civil brasileiro.

Imperioso salientar que a eventual invalidade do contrato de cessão temporária do útero não afasta os efeitos referentes aos direitos de filiação decorrentes dele, pois fora estabelecido diante da vontade procriacional das partes. ${ }^{133}$

131 LUCA, Ida Beatriz de. 0 direito contratual analisado à luz da hermenêutica dos princípios no panorama do direito comparado entre as fontes do direito contratual brasileiro e dos Estados Unidos da América: o caso do contrato de gestação de substituição. 2016. 259f. Tese (Doutorado em Direito) - Universidade do Vale do Rio dos Sinos, Programa de PósGraduação em Direito, São Leopoldo, 2016. Disponível em: < http://www. repositorio.jesuita.org.br/bitstream/handle/UNISINOS/6046/Ida\%20 Beatriz\%20de\%20Luca_pdf?sequence=1>. Acesso em: 02 out. 2018. p. 179.

132 SAUWEN, Regina Fiuza; HRYNIEWICZ, Severo. O Direito “in vitro” da bioética ao biodireito. 3. ed. Rio de Janeiro: Lumen Juris, 2008. p. 111.

133 AGUIAR, Mônica. Direito à filiação e bioética. Rio de Janeiro: Forense, 2005. p. 159. 
Godinho salienta que o acordo atribui a paternidade e a maternidade, em qualquer caso, ao casal que não pôde conceber os próprios filhos e não à gestante ou terceiros que eventualmente tenham doado óvulos ou sêmen. ${ }^{134}$

Conforme demonstrado, a gravidez e o parto perdem importância em se tratando de procriação assistida, sendo que a vontade torna-se o pressuposto de maior importância. Nas palavras de Gama: "não haveria gravidez nem parto se não fosse a vontade da mulher, que no exercício do direito ao planejamento familiar, e no bojo do projeto parental formulado com seu parceiro, desejou procriar". ${ }^{135}$

Nesse sentido, o Conselho Nacional de Justiça- CNJ editou o provimento no 52, de 14 de março de 2016, que regulamentou o registro dos filhos havidos por reprodução assistida, merecendo destaque o art. $2^{\circ}$, $\S 2^{\circ}$ que determinou que, independentemente de prévia autorização judicial, na hipótese de gestação por substituição, não deverá constar no registro o nome da parturiente, informado na declaração de nascido vivo - DNV. ${ }^{136}$ No ano de 2017, o CNJ editou novo provimento sob o tema (no 63, de 14 de novembro de 2017), revogando o provimento anterior, porém mantendo o mesmo conteúdo quanto à gestação por substituição (art. 17, §1ํㅜ) e acrescentando ao artigo a necessidade de apresentação de termo de compromisso firmado pela doadora temporária

134 GODINHO, Adriano Marteleto. Direito ao próprio corpo: direitos da personalidade e os atos de limitação voluntária. Curitiba: Juruá, 2015. p. 255.

135 GAMA, Guilherme Calmon Nogueira da. A nova filiação: o biodireito e as relações parentais: o estabelecimento da parentalidade-filiação e os efeitos jurídicos da reprodução assistida heteróloga. Rio de Janeiro: Renovar, 2003. p. 749.

136 CONSElHO NACIONAL DE JUSTIÇA. Provimento no 52, de 14 de março de 2016. Dispõe sobre o registro de nascimento e emissão da respectiva certidão dos filhos havidos por reprodução assistida. Disponível em: < http:// www.cnj.jus.br/files/conteudo/arquivo/2016/03/6bd953c10912313a24633f1a1e6535e1.pdf>. Acesso em: 03 out. 2018. 
do útero, esclarecendo a questão da filiação. ${ }^{137}$

Pelo exposto, verifica-se a sensibilidade do CNJ frente à lacuna deixada pela legislação quanto às questões atinentes a reprodução assistida, de maneira a uniformizar as decisões judiciais e preservar a dignidade dos filhos concebidos pelo uso dessas técnicas.

\section{CONSIDERAÇÕES FINAIS}

0 presente trabalho apresentou como escopo o estudo da cessão temporária de útero, método de reprodução humana assistida no qual há a participação de uma pessoa alheia ao projeto parental. 0 assunto enseja discussões em diversos campos: ético, religioso, social, cientifico e jurídico. No entanto, buscou-se a análise sob o viés jurídico através da verificação dos eventuais desdobramentos da utilização da técnica.

Primeiramente, procurou-se resgatar o papel da reprodução para o homem ao longo de sua história, dos primórdios até as descobertas recentes da ciência e que culminaram no desenvolvimento das técnicas de reprodução humana assistida. Verificaram-se ainda as presunções jurídicas adotadas para o estabelecimento da filiação e suas alterações diante da procriação assistida. Através dessa contextualização foi possível observar a importância do acesso às técnicas para aqueles em que a natureza impediu (ou dificultou) de gerar o próprio filho.

Em seguida, passou-se à análise da origem e conceito da cessão temporária de útero, bem como de sua adoção pelo

137 CONSELHO NACIONAL DE JUSTIÇA. Provimento no 63, de 14 de novembro de 2017. Institui modelos únicos de certidão de nascimento, de casamento e de óbito, a serem adotadas pelos ofícios de registro civil das pessoas naturais, e dispõe sobre o reconhecimento voluntário e a averbação da paternidade e maternidade socioafetiva no Livro "A" e sobre o registro de nascimento e emissão de respectiva certidão de filhos havidos por reprodução assistida. Disponível em: < http://www.cnj.jus.br/files/atos administrativos/provimento-n63-14-11-2017-corregedoria.pdf > . Acesso em: 03 out. 2018. 
Conselho Federal de Medicina entre as técnicas de reprodução humana assistida realizadas no Brasil. Por meio desse exame foi possível entendermos os critérios para que se faça o uso da gestação substitutiva, bem como os princípios adotados pelo CFM independentemente da técnica utilizada, os quais destacamos a necessidade de probabilidade de sucesso e a inexistência de risco para o paciente.

Posteriormente, foram abordados os direitos fundamentais que mais se relacionam à proteção da dignidade da pessoa humana em se tratando de reprodução assistida, com viés no aspecto civil e constitucional. Conclui-se que é aceitável a relativização desses direitos, através da ponderação dos mesmos na análise de um caso concreto, sendo necessário, no entanto, preservar o núcleo da dignidade da pessoa humana como limite à relativização.

Ao final, foram demonstradas as divergências doutrinárias relacionadas à admissibilidade, ou não, do estabelecimento de um contrato de cessão temporária de útero, gratuito ou oneroso. Foi possível conhecer os argumentos utilizados pelas duas correntes, favoráveis e desfavoráveis ao contrato, e verificar que o contrato gratuito possui maior aceitação pela doutrina, alinhando com o estabelecido atualmente pelo CFM em sua resolução.

Diante da pesquisa conclui-se que, inexistindo legislação que regulamente a cessão temporária de útero, pode ser estabelecido contrato entre as partes baseado essencialmente no direito à autonomia privada e à reprodução, porque em ambos os lados haveria interesse distinto sem prejuízo do direito alheio, culminando, portanto, na promoção à vida.

Tendo sido afastado o argumento de inobservância ao princípio da dignidade da pessoa humana, pois verificamos que o efeito direto da avença é a atribuição da paternidade aqueles que manifestaram a vontade de procriar. Portanto, incorreto dizer que há comercialização de pessoa humana, pois os autores do projeto parental já serão considerados os pais da criança, 
não necessitando "comprá-la". Ainda, se a vida humana não está sendo comercializada, admissível, portanto, a licitude do objeto contratual, corroborada pelo fato de que não haverá redução de partes do corpo da gestante, nem prejuízo à sua saúde.

Entre as cláusulas necessárias ao contrato estariam o custeio das despesas médicas e do parto e a irrevogabilidade do consentimento, exceto se a desistência for anterior à realização do procedimento de reprodução. A inobservância às cláusulas pelos contratantes ensejaria indenização.

Oportuno salientar que, mantida a Resolução do CFM, prudente será aquele contrato estabelecido de maneira gratuita, por generosidade, solidariedade e altruísmo, inexistindo qualquer margem à comercialização conforme prevê a norma atual.

Como última análise, é possível avaliar que o trabalho cumpriu com o proposto, pois o resultado atingiu os objetivos e confirmou a hipótese da pesquisa, além de poder, futuramente, servir de fomento às discussões relativas à lege ferenda que aborde $o$ assunto.

\section{REFERÊNCIAS}

AGUIAR, Mônica. Direito à filiação e bioética. Rio de Janeiro: Forense, 2005. ALEXY, Robert. Teoria dos Direitos Fundamentais. Trad. Virgílio A. Silva. São Paulo: Malheiros, 2008.

ALMEIDA, Aline Mignon de. Bioética e biodireito. Rio de Janeiro: Lumen Juris, 2000.

BÍBLIA. A. T. Gênesis. In: BÍBLIA. Português. Bíblia sagrada. Tradução de João Ferreira de Almeida. Sociedade Bíblica do Brasil, 1993. Disponível em: < http://biblia.com.br/joao-ferreira-almeida-corrigida-revisada-fiel/>. Acesso em: 04 out. 2018.

BOUZON, Emanuel (Org). 0 código de Hammurabi. 10. ed. Petrópolis: Vozes, 2003.

BRASIL. Constituição (1988). Constituição da República Federativa do Brasil. Disponível em: < http://www.planalto.gov.br/ccivil_03/ constituicao/constituicao.htm>. Acesso em: 3 out. 2018. 
. Decreto-lei no 4.657 de 04 de setembro de 1942 [Lei de Introdução às normas do Direito Brasileiro]. Disponível em: < http://www. planalto.gov.br/ccivil_03/decreto-lei/Del4657compilado.htm>. Acesso em: 13 mai. 2018.

. Lei no 10.406 de 10 de janeiro de 2002 [Código Civil Brasileiro]. Disponível em: < http://www.planalto.gov.br/CCivil_03/Leis/2002/ L10406.htm>. Acesso em: 13 mai. 2018.

Lei no 13.105 de 16 de março de 2015 [Código de Processo Civil]. Disponível em: < http://www.planalto.gov.br/ccivil_03/_ato20152018/2015/lei/l13105.htm>. Acesso em: 13 mai. 2018.

. Lei no 3.071 de 1o de janeiro de 1916 [Código Civil dos Estados Unidos do Brasil]. Disponível em: < http://www.planalto.gov.br/ ccivil_03/Leis/L3071.htm>. Acesso em: 13 mai. 2018.

. Lei no 9.434 de 4 de fevereiro de 1997 [Dispõe sobre a remoção de órgãos, tecidos e partes do corpo humano para fins de transplante e tratamento e dá outras providências]. Disponível em: $<$ http://www. planalto.gov.br/cciViL_03/LEIS/L9434.htm>. Acesso em: 25 set. 2018.

. Lei no 9.263 de 12 de janeiro de 1996. Regula o §7ㅇ do art. 226 da Constituição Federal, que trata do planejamento familiar, estabelece penalidades e dá outras providências. Disponível em: <http://www. planalto.gov.br/ccivil_03/leis/19263.htm>. Acesso em: 13 mai. 2018.

CHAVES, Antônio. Direito à vida e ao próprio corpo: intersexualidade, transexualidade, transplantes. 2. Ed. São Paulo: Revista dos Tribunais, 1994.

CONSELHO FEDERAL DE MEDICINA (CFM). Resolução CFM no 2.168/2017. Disponível em <https://sistemas.cfm.org.br/normas / visualizar/resolucoes/BR/2017/2168>. Acesso em: 26 set. 2018.

CONSELHO NACIONAL DE JUSTIÇA. Provimento no 52, de 14 de março de 2016. Dispõe sobre o registro de nascimento e emissão da respectiva certidão dos filhos havidos por reprodução assistida. Disponível em: < http://www.cnj.jus.br/files/conteudo/arquivo/2016/03/6bd953c109 12313a24633f1a1e6535e1.pdf>. Acesso em: 03 out. 2018.

Provimento no 63, de 14 de novembro de 2017. Institui modelos únicos de certidão de nascimento, de casamento e de óbito, a serem adotadas pelos ofícios de registro civil das pessoas naturais, e dispõe sobre o reconhecimento voluntário e a averbação da paternidade e maternidade socioafetiva no Livro "A" e sobre o registro de 
nascimento e emissão de respectiva certidão de filhos havidos por reprodução assistida. Disponível em: < http://www.cnj.jus.br/files/ atos_administrativos/provimento-n63-14-11-2017-corregedoria.pdf>. Acesso em: 03 out. 2018.

Declaração Universal dos Direitos Humanos. Assembleia Geral das Nações Unidas em Paris. 10 dez. 1948. Disponível em: < https://www. ohchr.org/EN/UDHR/Documents/UDHR_Translations/por.pdf>. Acesso em: 01 out. 2018.

DIAS, Maria Berenice. Manual de Direito das famílias. Porto Alegre: Livraria do Advogado, 2005.

Manual de Direito das famílias. 4.ed. São Paulo: Revista dos tribunais, 2016.

DINIZ, Maria Helena. 0 estado atual do biodireito. 2. ed. São Paulo: Saraiva, 2002.

FERRAZ, Sérgio. Manipulações biológicas e princípios constitucionais. Porto Alegre: Sete Mares, 1991.

GAMA, Guilherme Calmon Nogueira da. A nova filiação: o biodireito e as relações parentais: o estabelecimento da parentalidade-filiação e os efeitos jurídicos da reprodução assistida heteróloga. Rio de Janeiro: Renovar, 2003.

GIL, Antônio Carlos. Como elaborar projetos de pesquisa. 5. ed. São Paulo: Atlas, 2010.

GODINHO, Adriano Marteleto. Direito ao próprio corpo: direitos da personalidade e os atos de limitação voluntária. Curitiba: Juruá, 2015.

LAGRASTA NETO, Caetano; TARTUCE, Flávio; SIMÃO, José Fernando. Direito de família: novas tendências e julgamentos emblemáticos. 2.ed. São Paulo: Atlas, 2012.

LEITE, Eduardo de Oliveira (Coord). Grandes temas da atualidade: bioética e biodireito. Rio de Janeiro: Forense, 2004.

Procriações artificiais e o direito: aspectos médicos, religiosos, psicológicos, éticos e jurídicos. São Paulo: Revista dos Tribunais, 1995. LÔBO, Paulo. Princípio jurídico da afetividade na filiação. Revista Jus Navigandi, ISSN 1518-4862, Teresina, ano 5, n. 41, 1 maio 2000. Disponível em: <https://jus.com.br/artigos/527/>. Acesso em: 2 out. 2018. 
LOPES, Érica Camelo Viana; COSTA, Vanessa Duarte; BARCELOS, Rejane da Silva Sena. Banco de Dados de DNA na Área Forense: uma Realidade Brasileira. Brazilian Journal of Forensic Sciences, Goiás, v. 2, n. 4, 30 setembro 2013. Disponível em: < http://www.ipebj.com.br/forensicjournal/download.php?arquivo=100>. Acesso em: 12 nov. 2018.

LUCA, Ida Beatriz de. 0 direito contratual analisado à luz da hermenêutica dos princípios no panorama do direito comparado entre as fontes do direito contratual brasileiro e dos Estados Unidos da América: o caso do contrato de gestação de substituição. 2016. 259f. Tese (Doutorado em Direito) - Universidade do Vale do Rio dos Sinos, Programa de Pós-Graduação em Direito, São Leopoldo, 2016. Disponível em: <http://www.repositorio.jesuita.org.br/bitstream/handle/ UNISINOS/6046/Ida\%20Beatriz\%20de\%20Luca_.pdf?sequence=1>. Acesso em: 02 out. 2018.

MARCONI, Marina de Andrade. Metodologia científica. 6. ed., rev. e ampl. São Paulo: Atlas, 2011.

MASSON, Nathalia. Manual de Direito Constitucional. 4. ed. Salvador: Juspodivm, 2016.

MIRANDA, Pontes de. Atualizado por Vilson Rodrigues Alves. Tratado de Direito Privado: parte geral. Campinas: Bookseller, 2000. 2 v.

MORAES, Alexandre de. Direito Constitucional. 32. ed. São Paulo: Atlas, 2016.

PATRIOTA, Tania. Relatório da Conferência Internacional sobre a População e Desenvolvimento: Plataforma de Cairo. [entre 1995 e 2005]. Disponível em: http://www.unfpa.org.br/Arquivos/relatorio-cairo.pdf. Acesso em: 04 out. 2018.

PEREIRA, Caio Mário da Silva Pereira. Instituições de direito civil: introdução ao Direito Civil. 21. ed. Rio de Janeiro: Forense, 2006. v.1

SÁ, Maria de Fátima Freire de; NAVES, Bruno Torquato de Oliveira (Org). Bioética, biodireito e o novo Código Civil de 2002. Belo Horizonte: Del Rey, 2004.

SANTOS, Maria Celeste Cordeiro Leite (Org). Biodireito: ciência da vida, os novos desafios. São Paulo: Revista dos Tribunais, 2001.

SARLET, Ingo Wolfgang. Dignidade da pessoa humana e direitos fundamentais na Constituição Federal de 1988. Porto Alegre: Livraria do Advogado, 2008. 
SAUWEN, Regina Fiuza; HRYNIEWICZ, Severo. O Direito "in vitro" da bioética ao biodireito. 3. ed. Rio de Janeiro: Lumen Juris, 2008.

SEVERINO, Antônio Joaquim. Metodologia do trabalho científico. 23. ed. rev. e. atual. São Paulo: Cortez, 2007.

SILVA, Ivan de Oliveira. Biodireito, bioética e patrimônio genético brasileiro. São Paulo: Pillares, 2008.

VENOSA, Silvio de Salvo. Direito Civil: direito de família. 12. ed. São Paulo: Atlas, 2012. v. 6.

Direito civil: direito de família. 2. ed. São Paulo: Atlas, 2002.

Direito Civil: parte geral. 12. ed. São Paulo: Atlas, 2012. v. 1.

VENTURA, Miriam. Direitos Reprodutivos no Brasil. 3. ed. Brasília:\{s.n.\}, 2009.

VIOTTI, Maria Luiza Ribeiro. Declaração e plataforma de ação da IV Conferência Mundial sobre a mulher: Pequim. [entre 1995 e 2005]. Disponível em http://www.unfpa.org.br/Arquivos/declaracao_beijing. pdf. Acesso em: 04 out. 2018.

ZEGERS-HOCHSCHILD, F.; ADAMSON, G.D.; MOUZON, J.; ISHIHARA, O.; MANSOUR, R.; NYGREN, K.; SULLIVAN, E.; VANDERPOEL S. Glossário revisado da Terminologia das Técnicas de Reprodução Assistida (TRA), 2009, Comitê Internacional para Monitorização da Tecnologia Reprodutiva Assistida (ICMART) e Organização Mundial da Saúde (OMS). 2010. Disponível em: <http://www.who.int/reproductivehealth/publications/infertility/art_terminology_por.pdf >. Acesso em: 05 jun. 2018. 